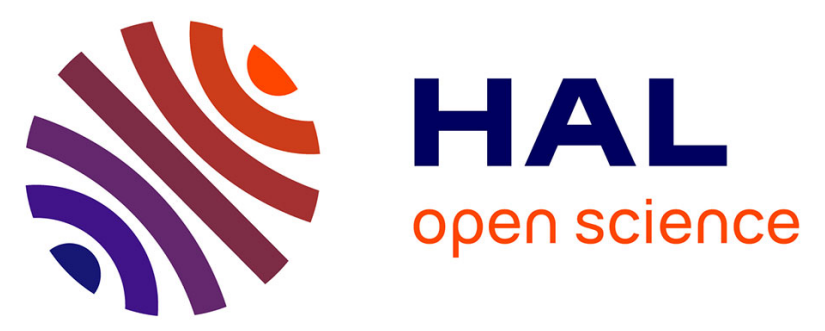

\title{
Comparative study of Yb:Lu3Al5O12 and Yb:Lu2O3 laser ceramics produced from laser-ablated nanopowders
} Liza Basyrova, Pavel Loiko, Roman Maksimov, Vladislav Shitov, Josep Maria Serres, Uwe Griebner, Valentin Petrov, Magdalena Aguiló, Francesc Díaz, Xavier Mateos

\section{To cite this version:}

Liza Basyrova, Pavel Loiko, Roman Maksimov, Vladislav Shitov, Josep Maria Serres, et al.. Comparative study of $\mathrm{Yb}: \mathrm{Lu} 3 \mathrm{~A} 15 \mathrm{O} 12$ and $\mathrm{Yb}: \mathrm{Lu} 2 \mathrm{O} 3$ laser ceramics produced from laser-ablated nanopowders. Ceramics International, 2021, 47 (5), pp.6633-6642. 10.1016/j.ceramint.2020.10.253 . hal-03368757

\section{HAL Id: hal-03368757 https://hal.science/hal-03368757}

Submitted on 7 Oct 2021

HAL is a multi-disciplinary open access archive for the deposit and dissemination of scientific research documents, whether they are published or not. The documents may come from teaching and research institutions in France or abroad, or from public or private research centers.
L'archive ouverte pluridisciplinaire HAL, est destinée au dépôt et à la diffusion de documents scientifiques de niveau recherche, publiés ou non, émanant des établissements d'enseignement et de recherche français ou étrangers, des laboratoires publics ou privés. 


\title{
Comparative study of $\mathrm{Yb}: \mathrm{Lu}_{3} \mathrm{Al}_{5} \mathrm{O}_{12}$ and $\mathrm{Yb}: \mathrm{Lu}_{2} \mathrm{O}_{3}$ laser ceramics produced from laser-ablated nanopowders
}

\author{
Liza Basyrova, ${ }^{1,2}$ Pavel Loiko, ${ }^{3}$ Roman Maksimov, ${ }^{4,5}$ Vladislav Shitov, ${ }^{5}$ Josep Maria \\ Serres, ${ }^{1}$ Uwe Griebner, ${ }^{6}$ Valentin Petrov, ${ }^{6}$ Magdalena Aguiló, ${ }^{1}$ Francesc Díaz, ${ }^{1}$ and \\ Xavier Mateos ${ }^{1, *}$
}

${ }^{1}$ Universitat Rovira i Virgili (URV), Física i Cristal-lografia de Materials i Nanomaterials (FiCMA-FiCNA), Marcel.li Domingo 1, 43007 Tarragona, Spain

${ }^{2}$ ITMO University, 49 Kronverkskiy Pr., 197101 Saint-Petersburg, Russia

${ }^{3}$ Centre de Recherche sur les Ions, les Matériaux et la Photonique (CIMAP), UMR 6252

CEA-CNRS-ENSICAEN, Université de Caen Normandie, 6 Boulevar du Maréchal Juin, 14050 Caen Cedex 4, France

${ }^{4}$ Ural Federal University, 19 Mira St., 620002 Ekaterinburg, Russia

${ }^{5}$ Institute of Electrophysics, Ural Branch of the Russian Academy of Sciences, 106 Amundsen St., 620016 Ekaterinburg, Russia

${ }^{6}$ Max Born Institute for Nonlinear Optics and Short Pulse Spectroscopy, Max-Born-Str. $2 a$, 12489 Berlin, Germany

*Corresponding author, e-mail: xavier.mateos@urv.cat

\begin{abstract}
We present a comparative study of two Lu-based oxide ceramics doped with $\mathrm{Yb}^{3+}$ ions, namely $\mathrm{Yb}: \mathrm{Lu}_{3} \mathrm{Al}_{5} \mathrm{O}_{12}$ (garnet) and $\mathrm{Yb}: \mathrm{Lu}_{2} \mathrm{O}_{3}$ (sesquioxide), promising for thin-disk lasers. The ceramics are fabricated using nanopowders of 3.6 at.\% $\mathrm{Yb}: \mathrm{Lu}_{2} \mathrm{O}_{3}$ and $\mathrm{Al}_{2} \mathrm{O}_{3}$ produced by laser ablation: $\mathrm{Yb}: \mathrm{Lu}_{3} \mathrm{Al}_{5} \mathrm{O}_{12}$ - by vacuum sintering at $1800{ }^{\circ} \mathrm{C}$ for $5 \mathrm{~h}$ with the addition of $1 \mathrm{wt} \%$ TEOS as a sintering aid, and $\mathrm{Yb}: \mathrm{Lu}_{2} \mathrm{O}_{3}$ - by vacuum pre-sintering at $1250{ }^{\circ} \mathrm{C}$ for $2 \mathrm{~h}$ followed by Hot Isostatic Pressing at $1400{ }^{\circ} \mathrm{C}$ for $2 \mathrm{~h}$ under Ar gas pressure of $207 \mathrm{MPa}$. The comparison includes the structure, Raman spectra, transmission, optical spectroscopy and laser operation. The crystal-field splitting of $\mathrm{Yb}^{3+}$ multiplets is revealed for $\mathrm{Lu}_{3} \mathrm{Al}_{5} \mathrm{O}_{12}$. A continuous-wave $(\mathrm{CW}) \mathrm{Yb}: \mathrm{Lu}_{3} \mathrm{Al}_{5} \mathrm{O}_{12}$ ceramic microchip laser generates $5.65 \mathrm{~W}$ at $1031.1 \mathrm{~nm}$ with a slope efficiency of $67.2 \%$. In the quasi-CW regime, the peak power is scaled up to $8.83 \mathrm{~W}$. The power scaling for the $\mathrm{Yb}: \mathrm{Lu}_{2} \mathrm{O}_{3}$ ceramic laser is limited by losses originating from residual coloration and inferior thermal behavior.
\end{abstract}

Keywords: garnets; sesquioxides; optical ceramics; laser operation. 


\section{Introduction}

Transparent ceramics are fully dense single-phase polycrystalline materials containing $\mu \mathrm{m}$-sized grains and featuring high light transmission in a broad spectral range [1,2]. High transmission is ensured by: (i) very small porosity, (ii) absence of a second phase at the grain boundaries - negligible difference of the optical properties between the grains and their boundaries, (iii) high quality grain boundaries, (iv) small grain size with narrow and spatially uniform size distribution, (v) isotropic lattice structure and (vi) high surface quality. Under such conditions, transparent ceramics are of interest for fabrication of photonic elements.

Recently, transparent ceramics doped with rare-earth ions $\left(\mathrm{RE}^{3+}\right)$ such as $\mathrm{Nd}^{3+}[3,4]$, $\mathrm{Yb}^{3+}[5,6], \mathrm{Tm}^{3+}[7], \mathrm{Ho}^{3+}[8]$, etc., have attracted research interest for implementation in near-infrared lasers. As defined by the condition of isotropic structure, cubic materials mainly belonging to two crystal families were employed for this aim, namely, garnets $\mathrm{RE}_{3} \mathrm{Al}_{5} \mathrm{O}_{12}$ $(\mathrm{RE}=\mathrm{Y}, \mathrm{Lu})[9,10]$ and sesquioxides $\mathrm{A}_{2} \mathrm{O}_{3}(\mathrm{~A}=\mathrm{Y}, \mathrm{Lu}, \mathrm{Sc}$ or their mixture $)$ [11-13]. Transparent laser ceramics offer several advantages as compared to the corresponding singlecrystals, i.e., (i) easier fabrication method, (ii) lower synthesis temperature (cf. the highmelting temperature sesquioxides [11,12]); (iii) higher $\mathrm{RE}^{3+}$ doping levels [5,14], (iv) sizescalable production and (v) possibility to fabricate compositionally "mixed" structures $[13,15]$.

The first studies on laser ceramics focused on $\mathrm{Nd}^{3+}$ doping for laser emission at $\sim 1.06$ $\mu \mathrm{m}[3,4]$. Later on, the interest shifted to the ytterbium $\left(\mathrm{Yb}^{3+}\right)$ ion $[5,6] . \mathrm{Yb}^{3+}$ provides broader emission bandwidth around $\sim 1 \mu \mathrm{m}$ allowing for wavelength tuning and generation of ultrashort pulses. The simple energy-level scheme eliminates energy-transfer upconversion. $\mathrm{Yb}^{3+}$-doped materials can be efficiently pumped by commercial and high-power InGaAs laser diodes at 930-980 $\mathrm{nm}$ leading to high Stokes efficiency and much weaker heat loading (as compared to the $\mathrm{Nd}^{3+}$-doped ones). $\mathrm{Yb}^{3+}$-doped laser ceramics are thus important for applications in power-scalable continuous-wave (CW) $[5,16,17]$ and mode-locked bulk $[18,19]$ and thin-disk [20] lasers at $\sim 1 \mu \mathrm{m}$.

It was shown that $\mathrm{Lu}$-based oxides (e.g., $\mathrm{Lu}_{3} \mathrm{Al}_{5} \mathrm{O}_{12}$ and $\mathrm{Lu}_{2} \mathrm{O}_{3}[10]$ ) are more suitable for $\mathrm{Yb}^{3+}$ doping as compared to their $\mathrm{Y}$-counterparts $[21,22]$. This is because of the relatively small difference of ionic radii between $\mathrm{Yb}^{3+}$ and $\mathrm{Lu}^{3+}$ which leads to weaker lattice distortions, lower scattering losses, easier doping with close to $100 \%$ segregation coefficient and better thermal properties. Lu-based oxides show much weaker dependences of thermal conductivity $\kappa$ on the $\mathrm{Yb}$ doping level and the temperature (as compared to Y-oxides) whilst the $\kappa$ values of undoped materials are close. The thermal conductivity of $\mathrm{Yb}_{2} \mathrm{Lu}_{3} \mathrm{Al}_{5} \mathrm{O}_{12}(\kappa$ $\sim 7.5 \mathrm{Wm}^{-1} \mathrm{~K}^{-1}$ for few at.\% $\mathrm{Yb}$ doping at room temperature) already becomes superior to that of $\mathrm{Yb}: \mathrm{Y}_{3} \mathrm{Al}_{5} \mathrm{O}_{12}$ at relatively low doping levels [21]. This has a direct influence on the power scaling capabilities of lasers [10].

Transparent $\mathrm{Yb}: \mathrm{Lu}_{3} \mathrm{Al}_{5} \mathrm{O}_{12}$ ceramics have been fabricated by different methods and their diode-pumped laser performance has been already studied [6,17,18,22,23]. It was shown that $\mathrm{Yb}: \mathrm{Lu}_{3} \mathrm{Al}_{5} \mathrm{O}_{12}$ ceramic lasers outperform those based on single-crystals [24]. Fu et al. reported on 2.5 at.\% $\mathrm{Yb}: \mathrm{Lu}_{3} \mathrm{Al}_{5} \mathrm{O}_{12}$ ceramics fabricated by solid-state sintering at $1850{ }^{\circ} \mathrm{C}$ for $50 \mathrm{~h}$ using commercial powders generating $2.1 \mathrm{~W}$ at $1030 \mathrm{~nm}$ with a slope efficiency of 
$41.7 \%$ [22]. Pirri et al. demonstrated a highly-doped 10 at.\% $\mathrm{Yb}: \mathrm{Lu}_{3} \mathrm{Al}_{5} \mathrm{O}_{12}$ ceramic laser diode-pumped at $936 \mathrm{~nm}$ delivering $6.0 \mathrm{~W}$ at $1030 \mathrm{~nm}$ with a slightly higher slope efficiency of 52\% [25]. $\mathrm{Yb}: \mathrm{Lu}_{3} \mathrm{Al}_{5} \mathrm{O}_{12}$ ceramic thin-disk lasers are also known: Nakao et al. developed such a thin-disk laser with an output power of $166 \mathrm{~W}$ and a slope efficiency of $72.2 \%$ [10].

Recently, we proposed a novel approach to fabricate transparent $\mathrm{Yb}: \mathrm{Lu}_{3} \mathrm{Al}_{5} \mathrm{O}_{12}$ ceramics by using laser-ablated $\mathrm{Yb}: \mathrm{Lu}_{2} \mathrm{O}_{3}$ and $\mathrm{Al}_{2} \mathrm{O}_{3}$ nanopowders and tetraethoxysilane (TEOS) as a sintering additive [26]. It allowed us to reduce the synthesis temperature down to $1800{ }^{\circ} \mathrm{C}$ while maintaining the good optical quality of the ceramics.

In the present work, we report on efficient and power-scalable diode-pumped operation of transparent $\mathrm{Yb}: \mathrm{Lu}_{3} \mathrm{Al}_{5} \mathrm{O}_{12}$ ceramics fabricated using laser-ablated nanoparticles by employing a compact (microchip-type) laser design. For comparison, we also studied $\mathrm{Yb}: \mathrm{Lu}_{2} \mathrm{O}_{3}$ ceramics produced from the corresponding laser-ablated nanopowder. The structural, optical and spectroscopic properties of the two ceramics are compared.

\section{Synthesis of ceramics}

For the fabrication of the $\mathrm{Yb}^{3+}$-doped ceramics, we used $\mathrm{Yb}: \mathrm{Lu}_{2} \mathrm{O}_{3}$ and $\mathrm{Al}_{2} \mathrm{O}_{3}$ nanopowders (mean particle size: $34 \mathrm{~nm}$ and $29 \mathrm{~nm}$, respectively) synthesized by laser ablation and subsequent sedimentation [26,27]. This approach allowed us to produce nanopowders with a narrow particle size distribution which has a positive effect on the transparency of ceramics.

To fabricate $\mathrm{Yb}: \mathrm{Lu}_{3} \mathrm{Al}_{5} \mathrm{O}_{12}$ garnet ceramics, both nanopowders were used. To achieve a stoichiometric $\mathrm{Al} /(\mathrm{Yb}+\mathrm{Lu})$ ratio corresponding to $\left(\mathrm{Yb}_{0.036} \mathrm{Lu}_{0.964}\right)_{3} \mathrm{Al}_{5} \mathrm{O}_{12}$ composition, the nanopowders were converted into the cubic phase by calcining at $900-1200{ }^{\circ} \mathrm{C}$ for 3 hours (h) in air. The calcined powders were weighed and mixed by ball milling in ethyl alcohol for $48 \mathrm{~h}$ with an addition of $1 \mathrm{wt} \%$ of TEOS $\left(\mathrm{Si}\left(\mathrm{OC}_{2} \mathrm{H}_{5}\right)_{4}\right)$ as a sintering aid. After drying, the mixture was compacted into a cylindrical pellet by uniaxial static pressing at $200 \mathrm{MPa}$. The obtained compact powder was sintered at $1800{ }^{\circ} \mathrm{C}$ for $5 \mathrm{~h}$ in a vacuum furnace with graphite heaters at a residual gas pressure of $10^{-3} \mathrm{~Pa}$. The as-sintered blue-colored ceramic disk (diameter: $\Phi=14 \mathrm{~mm}$, thickness: $t=2 \mathrm{~mm}$ ) was annealed in air at $1300{ }^{\circ} \mathrm{C}$ for $5 \mathrm{~h}$ to remove the coloration originating from oxygen vacancies and $\mathrm{Yb}^{2+}$ species appearing in oxygendeficient atmosphere [26,28]. As a result, a transparent and colorless sample was obtained, Fig. 1.

The formation of $\mathrm{SiO}_{2}$-rich liquid phase during sintering of $\mathrm{Yb}: \mathrm{Lu}_{3} \mathrm{Al}_{5} \mathrm{O}_{12}$ ceramics with the addition of TEOS promotes mass transfer and densification enabling almost porefree microstructure using conventional vacuum sintering. However, the complete elimination of pores in sesquioxides is difficult because the conventional sintering usually requires high temperatures for full densification, which often results in grain-entrapped pores due to a rapid grain growth at the final stage of sintering. One of the approaches to avoid the breakaway of pores from the grain boundaries is based on the reduction of the sintering temperature by using pressure-assisted densification methods such as Hot Isostatic Pressing (HIP). Consequently, to fabricate the $\mathrm{Yb}: \mathrm{Lu}_{2} \mathrm{O}_{3}$ ceramics, the laser-ablated $\mathrm{Yb}: \mathrm{Lu}_{2} \mathrm{O}_{3}$ nanopowder was compacted by uniaxial dry-pressing at $200 \mathrm{MPa}$ and then pre-sintered under vacuum at 
$1250{ }^{\circ} \mathrm{C}$ for $2 \mathrm{~h}$. The pre-sintered sample was subjected to a capsule-free post-HIP step under an Ar gas pressure of $207 \mathrm{MPa}$ at a temperature of $1400^{\circ} \mathrm{C}$ for $2 \mathrm{~h}$.

The obtained $\mathrm{Yb}: \mathrm{Lu}_{2} \mathrm{O}_{3}$ ceramic disk with dimensions similar to those for $\mathrm{Yb}: \mathrm{Lu}_{3} \mathrm{Al}_{5} \mathrm{O}_{12}$ was transparent but had a deep-brown coloration. The latter is assigned to oxygen vacancies forming during HIP in the oven with graphite heaters (forming reducer conditions). To remove the coloration, the ceramic was annealed in air. We studied the effect of annealing temperature and duration on the sample transmission, Fig. 2. For this, we used a similar $\mathrm{Yb}: \mathrm{Lu}_{2} \mathrm{O}_{3}$ sample obtained by vacuum pre-sintering at $1400{ }^{\circ} \mathrm{C}$ for $1 \mathrm{~h}$ followed by HIP at $1500{ }^{\circ} \mathrm{C}$ for $2 \mathrm{~h}$. For the annealing temperature of $1200{ }^{\circ} \mathrm{C}$ with increasing the treatment time from 1 to $10 \mathrm{~h}$, the in-line transmission of the ceramic disk $T_{0}$ gradually increases from $75.5 \%$ to $77.7 \%$ (at the wavelength of $1.10 \mu \mathrm{m}$ ) which is well above the transmission for the as-HIPed ceramics $\left(T_{0}=71.1 \%\right)$. Further increase of this time above $10 \mathrm{~h}$ does not improve the sample transmission. However, the annealing at $1300{ }^{\circ} \mathrm{C}$ for $1 \mathrm{~h}$ results in a notable drop of $T_{0}$. A similar effect was observed previously in [29] and was assigned to the intense growth of nm-sized pores at ambient pressure and temperature high enough to activate the solid-phase processes. Thus, the sample used for the laser studies was annealed at $1200{ }^{\circ} \mathrm{C}$ for $10 \mathrm{~h}$ in air, see Fig. 1. It maintained a weak grey-brown coloration.

The drop in the transmission in the visible spectral range for annealed $\mathrm{Yb}: \mathrm{Lu}_{2} \mathrm{O}_{3}$ ceramics (and, respectively, its residual coloration) may be explained as follows. First, it can originate from the presence of sub- $\mu \mathrm{m}$ and $\mathrm{nm}$ sized pores. According to the Rayleigh law, the scattering intensity is proportional to the squared volume of the defect and inverse proportional to $\lambda^{4}$. Considering that the content of scattering centers detected using optical microscopy is relatively low (see Section 2.2), we conclude that the scattering centers with characteristic diameter above $2 \mu \mathrm{m}$ cannot be responsible for the considerable decrease in light transmission at short wavelengths. Second, the coloration can be caused by impurity ions. We analyzed the impurity composition of the $\mathrm{Yb}: \mathrm{Lu}_{2} \mathrm{O}_{3}$ ceramic by Inductively Coupled Plasma Mass Spectrometry (ICP-MS) indicating the following uncontrolled impurities: transition-metal elements $-\mathrm{Mn}$ and $\mathrm{Ti}$ (both $\sim 12 \mathrm{ppm}$ ) and rare-earth ones $-\mathrm{Gd}$ and $\mathrm{Tb}$ (both $\sim 10 \mathrm{ppm}$ ) and Ho (7 ppm). Further discussion of the evidence for the presence of $\mathrm{Tb}^{3+}$ species in the ceramics is presented in Section 3.2.

The doping level for both ceramics is the same, 3.6 \pm 0.4 at.\%, determined by the composition of the $\mathrm{Yb}: \mathrm{Lu}_{2} \mathrm{O}_{3}$ nanoparticles analyzed using ICP-MS, while the ion density $N_{\mathrm{Yb}}$ is different, namely $5.1 \times 10^{20} \mathrm{~cm}^{-3}$ for $\mathrm{Yb}: \mathrm{Lu}_{3} \mathrm{Al}_{5} \mathrm{O}_{12}$ (measured density: $\rho=6.70 \mathrm{~g} / \mathrm{cm}^{3}$ ) and $10.2 \times 10^{20} \mathrm{~cm}^{-3}$ for $\mathrm{Yb}: \mathrm{Lu}_{2} \mathrm{O}_{3}\left(\rho=9.41 \mathrm{~g} / \mathrm{cm}^{3}\right)$.

For the spectroscopic studies, the disks were double-sided polished to laser-grade quality.

\section{Experimental}

The structure and the phase purity of the two ceramics were studied by X-ray powder diffraction (XRD) analysis using a Shimadzu XRD-6000 diffractometer and $\mathrm{Cu} \mathrm{K} \alpha$ radiation with a Ni filter. 
The distribution of scattering centers ( $\mu \mathrm{m}$-sized pores) through the depth of the ceramic disks was analyzed by direct counting using an optical microscope (Olympus BX51TRF). The selected disk volume $\left(577 \times 433 \times 50 \mu \mathrm{m}^{3}\right)$ was in-depth scanned starting from one sample surface and moving down reaching the opposite surface with a step of $50 \mu \mathrm{m}$ by changing the position of the focus. The spatial resolution of the microscope was $\sim 2 \mu \mathrm{m}$, so that smaller pores than this size were not visualized.

The microstructure of a fractured surface of both ceramics was studied by Scanning Electron Microscopy (SEM) using a MERLIN SEM microscope (Carl Zeiss), Fig. 5. The SEM images were analyzed with the ImageJ software counting $>100$ grains and a shape factor of 1.2 was applied.

The room temperature (RT, $293 \mathrm{~K}$ ) in-line transmission spectra of annealed and lasergrade polished ceramic disks were measured using a Shimadzu UV-3600 spectrophotometer. The luminescence spectra were measured with an optical spectrum analyzer (AQ6370B, Yokogawa) using a Ti:Sapphire laser tuned to $976 \mathrm{~nm}$ as an excitation source. For the lowtemperature (LT, $6 \mathrm{~K}$ ) absorption and luminescence studies, we used a cryostat (SU 12, Oxford Instruments Ltd.) with helium-gas close-cycle flow.

The luminescence decay curves were measured at RT for powdered samples to avoid the effect of radiation trapping. We used a $1 / 4 \mathrm{~m}$ monochromator (Oriel 77200), an InGaAs detector and an $8 \mathrm{GHz}$ digital oscilloscope (DSA70804B, Tektronix). The luminescence was excited by the output of a ns optical parametric oscillator (Horizon, Continuum) tuned to 970 $\mathrm{nm}$.

The RT Raman spectra were measured with a Renishaw inVia confocal Raman microscope using a $\times 50$ Leica objective (N.A. $=0.75)$. The excitation was at $488 \mathrm{~nm}\left(\mathrm{Ar}^{+}\right.$ion laser line) and the spectral resolution was $\sim 1 \mathrm{~cm}^{-1}$.

\section{Characterization of ceramics}

\subsection{Structure and microstructure}

The X-ray powder diffraction patterns of ceramics are shown in Fig. 3. Both ceramics are of single-phase nature. The $\mathrm{Yb}_{2} \mathrm{Lu}_{3} \mathrm{Al}_{5} \mathrm{O}_{12}$ ceramic exhibits a cubic structure identical to that of undoped $\mathrm{Lu}_{3} \mathrm{Al}_{5} \mathrm{O}_{12}$ (International Centre for Diffraction Data, ICDD card \#73-1368, sp. gr. Ia $^{-} d-\mathrm{O}^{10} \mathrm{~h}$, No. 230). The lattice constant is $a=11.912 \AA$. The $\mathrm{Yb}^{3+}$ ions in $\mathrm{Lu}_{3} \mathrm{Al}_{5} \mathrm{O}_{12}$ replace the host-forming $\mathrm{Lu}^{3+}$ cations in a single type of sites (symmetry: $\mathrm{D}_{2}$, coordination number (C.N.) by oxygen: VIII) and their ionic radii are $R_{\mathrm{Yb}}=0.985 \AA$ and $R_{\mathrm{Lu}}$ $=0.977 \AA$ [30]. This difference determines a slight increase of the lattice parameter $a$ with respect to undoped $\mathrm{Lu}_{3} \mathrm{Al}_{5} \mathrm{O}_{12}(a=11.90 \AA)$.

The $\mathrm{Yb}: \mathrm{Lu}_{2} \mathrm{O}_{3}$ ceramic is also cubic (sp. gr. $I a 3^{-}-T^{7}$ h, No. 206) and possesses the socalled bixbyite $\left((\mathrm{Mn}, \mathrm{Fe})_{2} \mathrm{O}_{3}\right.$-type) or C-type structure [31] of undoped $\mathrm{Lu}_{2} \mathrm{O}_{3}$ (ICDD card $\# 76-0162$ ). In the bixbyite structure, there are two crystallographic sites for $\mathrm{RE}^{3+}$ ions replacing the $\mathrm{Lu}^{3+}$ cations (symmetry: $\mathrm{C}_{2}$ and $\mathrm{C}_{3 i}, \mathrm{C} . \mathrm{N}$. by oxygen: VI). The optical properties are mainly determined by the majority of ions residing in the $\mathrm{C}_{2}$ sites (for the $\mathrm{C}_{3 i}$ site, the electric-dipole transitions are forbidden due to inversion symmetry) [32]. The $\mathrm{Yb}^{3+}$ ions in $\mathrm{Lu}_{2} \mathrm{O}_{3}$ have lower coordination than in garnets $\left(\mathrm{Lu}_{3} \mathrm{Al}_{5} \mathrm{O}_{12}\right)$ and shorter $\mathrm{Yb} \mid \mathrm{Lu}-\mathrm{O}$ 
interatomic distances leading to a stronger crystal field. The lattice constant for the $\mathrm{Yb}: \mathrm{Lu}_{2} \mathrm{O}_{3}$ ceramics is $a=10.401 \AA$, slightly larger compared to undoped $\mathrm{Lu}_{2} \mathrm{O}_{3}(a=10.391 \AA)$.

The results on the distribution of scattering centers ( $\mu \mathrm{m}$-sized pores) through the depth of the ceramic disks are shown in Fig. 4. The very high content of scattering centers near one of the surfaces is explained by the polishing quality (pre-polish prior to the actual laser-gradepolish). The mean concentration of $\mu \mathrm{m}$-sized pores $X_{\text {pore }}$ is $9.8 \mathrm{ppm}$ for $\mathrm{Yb}: \mathrm{Lu}_{3} \mathrm{Al}_{5} \mathrm{O}_{12}$ and 3.5 ppm for $\mathrm{Yb}: \mathrm{Lu}_{2} \mathrm{O}_{3}$ ceramics.

The SEM images of a fractured surface of both ceramics are shown in Fig. 5. The $\mathrm{Yb}: \mathrm{Lu}_{3} \mathrm{Al}_{5} \mathrm{O}_{12}$ ceramics exhibited a close-packed microstructure with relatively large grains (mean size: $D_{\text {grain }}=14 \mu \mathrm{m}$ ), clean grain boundaries and a very low content of sub- $\mu \mathrm{m}$ sized pores. The grain size distribution was similar over different parts of the ceramic disk. For the $\mathrm{Yb}: \mathrm{Lu}_{2} \mathrm{O}_{3}$ ceramics, much smaller grains were observed with $D_{\text {grain }}=0.4 \mu \mathrm{m}$. The ceramics also featured a close-packed structure. The difference in the mean grain size is related mainly to the different sintering temperature.

\subsection{Optical spectroscopy}

The in-line transmission spectra of annealed and laser-grade polished $\mathrm{Yb}: \mathrm{Lu}_{3} \mathrm{Al}_{5} \mathrm{O}_{12}$ and $\mathrm{Yb}: \mathrm{Lu}_{2} \mathrm{O}_{3}$ ceramic disks recalculated to the same thickness $t$ of $1.0 \mathrm{~mm}$ are shown in Fig. 6. They are compared with the upper limit of transmission set by the Fresnel losses.

For the $\mathrm{Yb}: \mathrm{Lu}_{3} \mathrm{Al}_{5} \mathrm{O}_{12}$ ceramic disk at the wavelength of $1.10 \mu \mathrm{m}$ (out of the $\mathrm{Yb}^{3+}$ absorption), the measured low-signal transmission was $T_{0}=83.0 \%$, which is very close to the theoretical limit, $T_{\mathrm{Fr}}=83.7 \%$ (calculated for a refractive index $n=1.824$ [33]). The ceramics also exhibited excellent transparency in the visible with the UV absorption edge at $\sim 230 \mathrm{~nm}$. For the $\mathrm{Yb}: \mathrm{Lu}_{2} \mathrm{O}_{3}$ ceramic disk, $T_{0}=81.3 \%$ at $1.10 \mu \mathrm{m}$, cf. with $T_{\mathrm{Fr}}=81.5 \%$ corresponding to a refractive index $n=1.909$ [34]. For this ceramic sample, the absorption in the visible gradually decreased reaching the UV absorption edge at $\sim 270 \mathrm{~nm}$.

The room temperature (RT, $293 \mathrm{~K}$ ) absorption cross-sections for $\mathrm{Yb}^{3+}$ were calculated from the absorption coefficient, $\sigma_{\mathrm{abs}}=\alpha_{\mathrm{abs}} / N_{\mathrm{Yb}}$, where $\alpha_{\mathrm{abs}}=-\ln \left(T_{0} / T_{\mathrm{Fr}}\right) / t$. For $\mathrm{Yb}: \mathrm{Lu}_{3} \mathrm{Al}_{5} \mathrm{O}_{12}$, at the zero-phonon line (ZPL, i.e., the transition between the lowest Stark sub-levels of $\mathrm{Yb}^{3+}$ multiplets), $\sigma_{\text {abs }}$ is $0.63 \times 10^{-20} \mathrm{~cm}^{2}$ at $968.4 \mathrm{~nm}$, see Fig. 7(a). The full width at half maximum (FWHM) of the absorption peak is $3.9 \mathrm{~nm}$. A broad (FWHM > $20 \mathrm{~nm}$ ) and structured absorption band is observed at shorter wavelengths with a maximum at $936.3 \mathrm{~nm}$. For $\mathrm{Yb}: \mathrm{Lu}_{2} \mathrm{O}_{3}, \sigma_{\mathrm{abs}}=1.77 \times 10^{-20} \mathrm{~cm}^{2}$ for the ZPL at $976.2 \mathrm{~nm}$ with a FWHM of $3.3 \mathrm{~nm}$.

The RT stimulated-emission (SE) cross-sections, $\sigma \mathrm{SE}$, were calculated using the reciprocity method (RM) [35]:

$$
\begin{aligned}
\sigma_{\mathrm{SE}}(\lambda) & =\sigma_{\mathrm{abs}}(\lambda) \frac{Z_{1}}{Z_{2}} \exp \left(-\frac{h c / \lambda-E_{\mathrm{ZPL}}}{k T}\right), \\
Z_{m} & =\sum_{k} g_{k}^{m} \exp \left(-E_{k}^{m} / k T\right) .
\end{aligned}
$$

Here, $h$ is the Planck constant, $c$ is the speed of light, $\lambda$ is the light wavelength, $k$ is the Boltzmann constant, $T$ is the crystal temperature, EzPL is the ZPL energy, and $Z_{\mathrm{m}}$ are the partition functions of the lower $(m=1)$ and the upper $(m=2)$ multiplets, $g^{\mathrm{m}_{\mathrm{k}}}$ (assumed to be 
1) is the degeneracy of the sub-level with the number $k$ and the energy $E^{\mathrm{m}_{\mathrm{k}}}$ measured from the lowest sub-level of each multiplet. The Stark splitting for $\mathrm{Yb}^{3+}: \mathrm{Lu}_{3} \mathrm{Al}_{5} \mathrm{O}_{12}$ was determined from low-temperature (LT) spectroscopy, and for $\mathrm{Yb}^{3+}: \mathrm{Lu}_{2} \mathrm{O}_{3}-$ was taken from [36]. The resulting SE cross-section spectra are shown in Fig. 7(a),(c).

In the long-wavelength part of the SE cross-section spectrum, the application of the RM leads to high uncertainty, so the Füchtbauer-Ladenburg (F-L) equation [37] was additionally employed. We used the following values of the radiative lifetime of the ${ }^{2} \mathrm{~F}_{5 / 2}$ state giving a good agreement between the two methods: $\tau_{\text {rad }}=1.01 \mathrm{~ms}\left(\mathrm{Yb}: \mathrm{Lu}_{3} \mathrm{Al}_{5} \mathrm{O}_{12}\right)$ and $0.805 \mathrm{~ms}$ $\left(\mathrm{Yb}: \mathrm{Lu}_{2} \mathrm{O}_{3}\right)$ which agrees well with previous studies [24,38].

For $\mathrm{Yb}: \mathrm{Lu}_{3} \mathrm{Al}_{5} \mathrm{O}_{12}$, the maximum $\sigma \mathrm{SE}$ is $2.46 \times 10^{-20} \mathrm{~cm}^{2}$ at a wavelength of $1030.2 \mathrm{~nm}$ which is longer than the ZPL transition. For $\mathrm{Yb}: \mathrm{Lu}_{2} \mathrm{O}_{3}$, the maximum $\sigma \mathrm{SE}$ is $1.65 \times 10^{-20} \mathrm{~cm}^{2}$ at $976.2 \mathrm{~nm}$ (the ZPL). At longer wavelengths, where the laser operation is expected, the SE cross-sections are lower, namely $0.86 \times 10^{-20} \mathrm{~cm}^{2}$ at $1033.0 \mathrm{~nm}$.

$\mathrm{The} \mathrm{Yb}^{3+}$ ion represents a quasi-three-level laser scheme with reabsorption. The gain cross-sections, $\sigma_{\text {gain }}=\beta \sigma \mathrm{SE}-(1-\beta) \sigma_{\mathrm{abs}}$, are thus calculated to conclude about the expected laser wavelengths. Here, $\beta=N_{2}\left({ }^{2} \mathrm{~F}_{5 / 2}\right) / N_{\mathrm{Yb}}$ is the inversion ratio $\left(N_{2}\right.$ is the fraction of $\mathrm{Yb}^{3+}$ ions in the upper laser level). The gain spectra are shown in Fig. 7(b),(d). For Yb:Lu3Als $\mathrm{O}_{12}$, the spectra are only weakly dependent on the inversion level showing a maximum at $\sim 1030$ $\mathrm{nm}$ and a gain bandwidth (FWHM) of $6.7 \mathrm{~nm}$ for $\beta=0.20$. For $\mathrm{Yb}: \mathrm{Lu}_{2} \mathrm{O}_{3}$, at small inversion ratios, $\beta<0.10$, the local peak at $\sim 1080 \mathrm{~nm}$ dominates in the spectra and for higher inversion ratios, another peak at $1033 \mathrm{~nm}$ appears. The gain bandwidth is $14.7 \mathrm{~nm}$ for $\beta=0.20$.

The crystal-field splitting for $\mathrm{Yb}^{3+}: \mathrm{Lu}_{3} \mathrm{Al}_{5} \mathrm{O}_{12}$ ceramics was determined using the LT (6 K) absorption and luminescence studies, as shown in Fig. 8(a),(b). The spectra were interpreted using the Raman spectra (see Fig. 10) to assign the phonon sidebands (marked by " $h v ")$. Each ${ }^{2 \mathrm{~S}+1} \mathrm{LJ}_{\mathrm{J}}$ multiplet splits into $J+1 / 2$ components numbered as $i=0 . .3\left({ }^{2} \mathrm{~F}_{7 / 2}\right.$, ground-state) and $j^{\prime}=0^{\prime} . .2^{\prime}\left({ }^{2} \mathrm{~F}_{5 / 2}\right.$, excited-state). As a result, we determined the following set of energy levels: 0, 602, 643 and $764 \mathrm{~cm}^{-1}\left({ }^{2} \mathrm{~F}_{7 / 2}\right), 10333,10643$ and $10908 \mathrm{~cm}^{-1}\left({ }^{2} \mathrm{~F}_{5 / 2}\right)$, Fig. 8(c). Thus, $E_{\mathrm{ZPL}}=10333 \mathrm{~cm}^{-1}$ and the partition functions $Z_{1}=1.122$ and $Z_{2}=1.277$, so that $\mathrm{Z}_{1} / \mathrm{Z}_{2}=0.879$. The determined Stark splitting is close to that reported previously for highly-doped (15 at.\%) $\mathrm{Yb}: \mathrm{Lu}_{3} \mathrm{Al}_{5} \mathrm{O}_{12}$ single-crystal, i.e., 0, 600, 635 and $762 \mathrm{~cm}^{-1}\left({ }^{2} \mathrm{~F}_{7 / 2}\right)$, 10330, 10645 and $10900 \mathrm{~cm}^{-1}\left({ }^{2} \mathrm{~F}_{5 / 2}\right)$ [24].

For both studied ceramics, the decay curves are clearly single-exponential, Fig. 9, corresponding to the luminescence lifetimes $\tau_{\text {lum }}=1.01 \mathrm{~ms}$ (for $\mathrm{Yb}: \mathrm{Lu}_{3} \mathrm{Al}_{5} \mathrm{O}_{12}$ ) and $0.74 \mathrm{~ms}$ (for $\mathrm{Yb}: \mathrm{Lu}_{2} \mathrm{O}_{3}$ ).

The RT Raman spectra are shown in Fig. 10. The cubic garnet structure of $\mathrm{Lu}_{3} \mathrm{Al}_{5} \mathrm{O}_{12}$ gives rise to 25 Raman-active modes (irreducible representations: $3 \mathrm{~A}_{1 \mathrm{~g}}+8 \mathrm{E}_{\mathrm{g}}+14 \mathrm{~F}_{2 \mathrm{~g}}$ ) [39]. The most intense band at $374 \mathrm{~cm}^{-1}$ assigned as $A_{1 \mathrm{~g}}\left(\mathrm{FWHM}=11 \mathrm{~cm}^{-1}\right)$ is due to the rotation of the $\left[\mathrm{AlO}_{4}\right]$ tetrahedral unit. The second intense mode at $796 \mathrm{~cm}^{-1}$ (also $\mathrm{A}_{1 \mathrm{~g}}, \mathrm{FWHM}=14$ $\mathrm{cm}^{-1}$ ) is due to the breathing mode of the $\left[\mathrm{AlO}_{4}\right]$ tetrahedrons. The maximum phonon energy is $869 \mathrm{~cm}^{-1}$. The cubic sesquioxide structure of $\mathrm{Lu}_{2} \mathrm{O}_{3}$ has 22 Raman-active modes $\left(4 \mathrm{Ag}_{\mathrm{g}}+4 \mathrm{E}_{\mathrm{g}}\right.$ $+14 \mathrm{Fg}_{\mathrm{g}}$ [40]. The most prominent band at $389 \mathrm{~cm}^{-1}\left(\mathrm{FWHM}=11 \mathrm{~cm}^{-1}\right)$ is ascribed to the $\mathrm{Ag}$ $+\mathrm{F}_{\mathrm{g}}$ vibrations and the maximum phonon energy is $\sim 610 \mathrm{~cm}^{-1}$. 


\section{Laser operation}

\subsection{Laser set-up}

For the laser experiments, we fabricated two rectangular ceramic elements with the following dimensions: $\mathrm{Yb}: \mathrm{Lu}_{3} \mathrm{Al}_{5} \mathrm{O}_{12}\left(t=2.75(z) \mathrm{mm}\right.$, aperture: $\left.3.18(x) \times 1.50 \mathrm{~mm}^{2}\right)$ and $\mathrm{Yb}: \mathrm{Lu}_{2} \mathrm{O}_{3}\left(t=1.07(z) \mathrm{mm}\right.$, aperture: $\left.2.5(x) \times 2.5 \mathrm{~mm}^{2}\right)$, where $x$ denotes an arbitrary direction lies in the plane of the ceramic disk and $z$-axis is orthogonal to it, respectively, cf. Fig. 1. Their input and output facets were polished to laser-grade quality and remained uncoated. The elements were wrapped in an Indium foil and mounted in a $\mathrm{Cu}$-holder for better heat removal from all four lateral sides. The holder was cooled by circulating water $\left(12{ }^{\circ} \mathrm{C}\right)$. The elements were placed in a compact (microchip-type) laser cavity formed by a flat pump mirror (PM) providing high transmission (HT) at $\sim 0.97 \mu \mathrm{m}$ and high reflectance (HR) at $1.02-1.23 \mu \mathrm{m}$, and a set of flat output couplers (OCs) with a transmission $T_{\mathrm{OC}}=0.5 \%-10 \%$ at 1.02-1.10 $\mu \mathrm{m}$, Fig. 11. The PM and the OC were placed close to the laser element so that the geometrical cavity length was close to the element thickness. The mode stabilization in a plano-plano cavity was provided by the positive thermal lens in both materials.

The pump source was a fiber-coupled (N.A. $=0.22$, fiber core diameter: $105 \mu \mathrm{m}$ ) InGaAs laser diode (LD) emitting up to $54 \mathrm{~W}$ of unpolarized output at $968 \mathrm{~nm}$ (emission linewidth: $1.5 \mathrm{~nm}, \mathrm{M}^{2} \approx 37$ ). Thus, the pumping was at the $\mathrm{ZPL}$ of $\mathrm{Yb}^{3+}$ ions in $\mathrm{Lu}_{3} \mathrm{Al}_{5} \mathrm{O}_{12}$ ceramics. This approach (compared to pumping at $936 \mathrm{~nm}$ [25]) has the advantage of reduced heat load. The pump was reimaged into the ceramic by an antireflection (AR) coated 1:1 lens assembly ( $\mathrm{f}=30 \mathrm{~mm}$ ) leading to a pump spot diameter $2 w_{\mathrm{P}} \approx 100 \mu \mathrm{m}$ and a confocal parameter $2 z \mathrm{R} \approx 1 \mathrm{~mm}$ (in the gain element). The OCs provided high reflection at the pump wavelength $(R>90 \%)$, so that the pumping was in a double-pass increasing the total pump absorption. The latter was determined from pump-transmission measurements at the laser

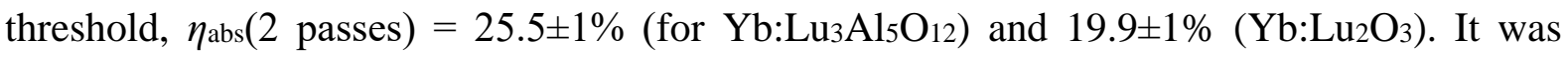
possible to operate the diode in quasi-CW regime by electronic modulation of the driving current.

The size of the laser mode in the ceramic laser element $2 w_{\mathrm{L}}$ was calculated using the $\mathrm{ABCD}$ formalism accounting for the thermal lens to be $55 \pm 7 \mu \mathrm{m}$ (for $\mathrm{Yb}_{\mathrm{Lu}} \mathrm{Lu}_{3} \mathrm{Al}_{5} \mathrm{O}_{12}$ ) and $47 \pm 5 \mu \mathrm{m}$ (for $\mathrm{Yb}: \mathrm{Lu}_{2} \mathrm{O}_{3}$ ).

The laser output was separated from the residual pump using a long-pass filter (FEL1000, Thorlabs). The spectra were measured using a spectrometer (APE, WaveScan; 800-1600 nm).

\subsection{Laser performance}

First, we studied the performance of the $\mathrm{Yb}: \mathrm{Lu}_{3} \mathrm{Al}_{5} \mathrm{O}_{12}$ ceramics limiting the absorbed pump power to $P_{\text {abs }}<5 \mathrm{~W}$, Fig. 12(a). Under such conditions, we did not observe any thermal effects (e.g., roll-over in the output dependence) when operating the laser in true $\mathrm{CW}$ regime. For the highest available output coupling $\left(T_{\mathrm{OC}}=10 \%\right)$, the laser generated $2.72 \mathrm{~W}$ at 1031.1 $\mathrm{nm}$ with a slope efficiency $\eta=67.2 \%$. The optical-to-optical efficiency $\eta_{\mathrm{opt}} \mathrm{vs}$. the pump power incident on the ceramic element was only $15.0 \%$, mostly because of the limited pump 
absorption. The laser threshold slightly increased with the output coupling, from $P_{\text {th }}=0.30 \mathrm{~W}$ (for $T_{\mathrm{OC}}=0.5 \%$ ) to $0.45 \mathrm{~W}$ (for $T_{\mathrm{OC}}=10 \%$ ).

The laser spectra were weakly dependent on the output coupling, Fig. 12(b). The laser oscillation occurred at $\sim 1030 \mathrm{~nm}$ in agreement with the gain spectra, Fig. 7(b). The laser emission was unpolarized. The multi-line structure of the emission spectra is due to etalon (Fabry-Perot) effects at the interfaces of the laser element / cavity mirrors.

The $\mathrm{Yb}: \mathrm{Lu}_{3} \mathrm{Al}_{5} \mathrm{O}_{12}$ ceramic laser operated in the fundamental transverse mode. The example profile of the laser mode (measured using $T_{\mathrm{OC}}=10 \%$ ) in the far-field is shown in Fig. 11(b). It is nearly circular. For $P_{\text {abs }}<5 \mathrm{~W}$, the beam profile was weakly dependent on the pump level.

The performance of the $\mathrm{Yb}: \mathrm{Lu}_{3} \mathrm{Al}_{5} \mathrm{O}_{12}$ ceramic laser for $T_{\mathrm{OC}}=10 \%$ was analyzed using the model of a quasi-three-level gain medium [41] yielding a double-pass intracavity loss $L$ of $4.1 \%$. This value is lower than the Fresnel losses at the uncoated surfaces of the laser element as it was polished with a good parallelism thus acting as a Fabry-Perot etalon. Thus, the coefficient of passive losses $\delta_{\text {loss }}=0.076 \pm 0.05 \mathrm{~cm}^{-1}$.

For the $\mathrm{Yb}: \mathrm{Lu}_{2} \mathrm{O}_{3}$ ceramics, we limited the absorbed pump power to $P_{\mathrm{abs}}<2 \mathrm{~W}$. The laser generated a maximum output power of $0.59 \mathrm{~W}$ at $1080-1084 \mathrm{~nm}$ with $\eta=38.0 \%$ and the optical-to-optical efficiency $\eta_{\mathrm{opt}}$ of $5.8 \%\left(T_{\mathrm{OC}}=5 \%\right)$. The laser threshold gradually increased with the output coupling, from $P_{\text {th }}=0.22 \mathrm{~W}$ (for $T_{\mathrm{OC}}=0.5 \%$ ) to $0.48 \mathrm{~W}$ (for $T_{\mathrm{OC}}=10 \%$ ). A reduction in the laser threshold for small output coupling, as compared to the $\mathrm{Yb}: \mathrm{Lu}_{3} \mathrm{Al}_{5} \mathrm{O}_{12}$ laser is due to the smaller thickness of the $\mathrm{Yb}: \mathrm{Lu}_{2} \mathrm{O}_{3}$ laser element. A thermal roll-over was observed in the output dependences for $P_{\mathrm{abs}}>2 \mathrm{~W}$. The emission occurred at $\sim 1080 \mathrm{~nm}$ for low $T_{\mathrm{OC}} \leq 5 \%$ and the laser wavelength experienced a blue-shift to $1036 \mathrm{~nm}$ for higher $T_{\mathrm{OC}}$, in agreement with the gain spectra, Fig. 7(d).

A notable reduction in the slope efficiency for the $\mathrm{Yb}: \mathrm{Lu}_{2} \mathrm{O}_{3}$ laser as compared to its garnet counterpart is mainly attributed to non-optimum mode-matching owing to the shorter cavity and thermal lens. To confirm this, we designed a hemispherical laser cavity with a concave (radius of curvature: $-50 \mathrm{~mm}$ ) output coupler. The calculated size of the laser mode in the ceramic element for this cavity geometry amounted to $55 \pm 5 \mu \mathrm{m}$, i.e., much closer to the pump spot size. The CW output power reached $1.0 \mathrm{~W}$ at $1083 \mathrm{~nm}$ with $\eta=68.0 \%$ and a laser threshold of $0.28 \mathrm{~W}$, see Fig. 12(c). Still, we were unable to avoid the thermal roll-over at $P_{\text {abs }}>2 \mathrm{~W}$. The analysis of the laser performance yielded a double-pass loss $L$ of $1.6 \%$ corresponding to $\delta_{\text {loss }}=0.077 \pm 0.05 \mathrm{~cm}^{-1}$ (i.e., almost the same as for the garnet ceramics). Thus, the difference in the power scaling capabilities for the two ceramics is mainly related to their different thermal behavior. One should also consider much longer emission wavelength for the $\mathrm{Yb}: \mathrm{Lu}_{2} \mathrm{O}_{3}$ ceramics leading to higher fractional heat loading, $\eta_{\mathrm{h}} \approx 1-\lambda_{\mathrm{P}} / \lambda_{\mathrm{L}}=10.6 \%$ (cf. with $6.1 \%$ for $\mathrm{Yb}: \mathrm{Lu}_{3} \mathrm{Al}_{5} \mathrm{O}_{12}$ ).

Subsequently the pump power for the $\mathrm{Yb}: \mathrm{Lu}_{3} \mathrm{Al}_{5} \mathrm{O}_{12}$ ceramic micro-laser was increased to the maximum available from the laser diode, Fig. 13(a). It corresponded to $P_{\text {abs }}=13.7 \mathrm{~W}$. In the $\mathrm{CW}$ regime, the laser generated $5.65 \mathrm{~W}$. As a result of the thermal roll-over in the input-output dependence for $P_{\mathrm{abs}}>5 \mathrm{~W}, \eta_{\mathrm{opt}}$ dropped to $10.5 \%$. To reduce the heat loading, the laser was operated in quasi-CW regime with different duty cycles (from 1:1.5 to 1:3). The 
duration of the rectangular pump pulses was $1 \mathrm{~ms}$ in all cases. With increasing the time interval between the pump pulses, the peak output power increased and the input-output dependence became linear reaching maximum values of $P_{\text {out,peak }}=8.83 \mathrm{~W}$ and $\eta=66.9 \%$, respectively, almost reproducing the slope of the true $\mathrm{CW}$ performance in the low-power regime.

To improve the thermal management of the ceramic laser, we also fabricated a slabshaped $\mathrm{Yb}: \mathrm{Lu}_{3} \mathrm{Al}_{5} \mathrm{O}_{12}$ element with a thickness of $3.18(x) \mathrm{mm}$ and aperture of $1.0(z) \times 2.75$ $\mathrm{mm}^{2}$. Cooling was provided at the two large-area lateral faces. The pump absorption in the slab slightly increased to $28.8 \pm 1 \%$ ( 2 passes). The input-output characteristics of the microslab ceramic laser are shown in Fig. 13(b) and compared with those for the microchip design. In the $\mathrm{CW}$ regime, the mini-slab laser generated $5.0 \mathrm{~W}$ at $1031.2 \mathrm{~nm}$ with improved $\eta=$ $78.8 \%$ (fitting the linear part of the output dependence), a laser threshold of $0.58 \mathrm{~W}$ and $\eta_{\mathrm{opt}}=$ $15.0 \%\left(T_{\mathrm{OC}}=10 \%\right)$. Still, a thermal roll-over was observed for $P_{\text {abs }}$ above $\sim 6 \mathrm{~W}$. We assign the improved slope efficiency to better mode-matching and probably weaker thermal lens in the laser element owing to its better cooling.

Note that the cut of the ceramic laser element (i.e., the propagation direction of the laser) of the micro-laser was orthogonal to the plane of the ceramic disk ( $\| z$-axis) while the cut of the slab element was lying on the plane of the disk ( $\| x$-axis, see Fig. 1). No deterioration of the laser performance is observed in the latter case, indicating good uniformity of the ceramic disk in the radial direction and highlighting its suitability for laser applications. Transparent ceramics fabricated on the basis of cubic materials exhibit no anisotropy of optical properties. However, one may observe anisotropy of pore distribution in the ceramic disk (and, consequently, the related anisotropy of scattering losses) under synthesis conditions when the pores are predominantly removed along one direction, e.g., when using hot (uniaxial) pressing or spark plasma synthesis. The lack of such effects for the studied ceramics was confirmed by analyzing the distribution of scattering centers and the grain size distribution across the ceramic disks (the difference was within the measurement error).

\subsection{Discussion}

The present work reports the first $\mathrm{CW}$ laser operation of $\mathrm{Yb}: \mathrm{Lu}_{3} \mathrm{Al}_{5} \mathrm{O}_{12}$ and $\mathrm{Yb}: \mathrm{Lu}_{2} \mathrm{O}_{3}$ ceramics obtained from laser-ablated nanoparticles.

Regarding previously reported $\mathrm{Yb}: \mathrm{Lu}_{3} \mathrm{Al}_{5} \mathrm{O}_{12}$ lasers based on single-crystals and ceramics, cf. Table 1, we obtained one of the best results in terms of output power (CW and quasi-CW operation) and slope efficiency, with highly compact (microchip-type) laser geometries. Microchip $\mathrm{Yb}: \mathrm{Lu}_{3} \mathrm{Al}_{5} \mathrm{O}_{12}$ lasers were reported by Dong et al. using 5 at.\% $\mathrm{Yb}$ doped single-crystals delivering a maximum $\mathrm{CW}$ output power of $1.63 \mathrm{~W}$ at $1030 \mathrm{~nm}$ with $\eta$ $=72 \%$. Much better output performance is achieved in the present work with the new ceramic material.

Using $\mathrm{Yb}: \mathrm{Lu}_{2} \mathrm{O}_{3}$ ceramics, multi-watt $\mathrm{CW}$ laser output has been previously reported by other researchers, e.g., Sanghera et al. demonstrated a diode-pumped 10 at.\% $\mathrm{Yb}: \mathrm{Lu}_{2} \mathrm{O}_{3}$ laser 
delivering $\sim 16 \mathrm{~W}$ at $1080 \mathrm{~nm}$ with $\eta=74 \%$ [44]. However, a much larger pump spot size (as compared to the present work) was used thus reducing the localized heat release.

Let us discuss the reasons for the thermal roll-over observed for the $\mathrm{Yb}: \mathrm{Lu}_{2} \mathrm{O}_{3}$ ceramic laser. The thermal conductivity of $\mathrm{Yb}: \mathrm{Lu}_{2} \mathrm{O}_{3}$ ceramics is high $\left(\kappa=13.9 \mathrm{Wm}^{-1} \mathrm{~K}^{-1}\right.$ for 3 at. $\%$ $\mathrm{Yb}$ doping [10]) and is weakly dependent on the $\mathrm{Yb}$ doping level [45]; moreover, it is higher than that for $\mathrm{Yb}: \mathrm{Lu}_{3} \mathrm{Al}_{5} \mathrm{O}_{12}$ [10]. This difference would compensate for the higher fractional heat load in $\mathrm{Yb}: \mathrm{Lu}_{2} \mathrm{O}_{3}$ originating from the longer emission wavelength. As determined in the present work, the passive losses in both materials at the laser wavelength are very close. Thus, another mechanism should be the reason.

It was suggested that the interaction of $\mathrm{Yb}^{3+}$ laser-active ions with uncontrolled rareearth impurities such as $\mathrm{Tb}^{3+}, \mathrm{Ho}^{3+}$ or $\mathrm{Dy}^{3+}$ may affect the output performance of $\mathrm{Yb}$ ceramic lasers [25,45]. Such ions are always present in the $\mathrm{Yb}_{2} \mathrm{O}_{3}$ and $\mathrm{Lu}_{2} \mathrm{O}_{3}$ raw materials. In addition, $\mathrm{Yb}^{2+}$ ions may play a similar role and act as quenching centers for $\mathrm{Yb}^{3+}$. Typically, $\mathrm{Yb}^{2+}$ ions formed during the synthesis in oxygen-deficient conditions are completely removed after annealing in air unless a charge compensation is present by a tetravalent impurity center such as $\mathrm{Tb}^{4+}$. Terbium is polyvalent and $\mathrm{Tb}^{4+}$ species can be formed during the oxidizing annealing preventing complete removal of $\mathrm{Yb}^{2+}$. Indeed, an unwanted energy transfer from $\mathrm{Yb}^{3+}$ ions to such impurity centers will lead to additional heat generation.

To clarify this issue, we measured the luminescence spectra of $\mathrm{Yb}^{3+}$-doped ceramics under excitation in the blue, Fig. 14(a), using the Renishaw inVia confocal Raman microscope. For the $\mathrm{Yb}: \mathrm{Lu}_{2} \mathrm{O}_{3}$ ceramics, we observed intense characteristic emissions of $\mathrm{Tb}^{3+}$ ions owing to the ${ }^{5} \mathrm{D}_{4} \rightarrow{ }^{5} \mathrm{~F}_{\mathrm{J}}(J=5 \ldots 0)$ transitions in addition to $\mathrm{Yb}^{3+}$ emission at $\sim 1 \mu \mathrm{m}$ which was at least one order or magnitude more intense. The spectral shape of the $\mathrm{Yb}^{3+}$ luminescence well matched the one observed under near-IR excitation. Although $\mathrm{Tb}^{3+}$ does not exhibit energy-levels being resonant in energy with the excited-state of $\mathrm{Yb}^{3+}$ (the energy of the metastable $\mathrm{Tb}^{3+}$ state ${ }^{5} \mathrm{D}_{4}$ is $\sim 20500 \mathrm{~cm}^{-1}$ whereas the energy of the $\mathrm{Yb}^{3+}$ excited-state ${ }^{2} \mathrm{~F}_{5 / 2}$ is $\sim 10000 \mathrm{~cm}^{-1}$ ), the bidirectional energy-transfer (ET) between these ions is known. It involves $\mathrm{Yb}^{3+}-\mathrm{Yb}^{3+}$ ion pairs exhibiting an excited-state with an energy $2 E\left({ }^{2} \mathrm{~F}_{5 / 2}\right) \sim 20000 \mathrm{~cm}^{-}$ ${ }^{1}$ leading either to cooperative sensitization $\left(2 \mathrm{Yb}^{3+} \rightarrow \mathrm{Tb}^{3+} \mathrm{ET}\right)$ [46] or cooperative downconversion $\left(\mathrm{Tb}^{3+} \rightarrow 2 \mathrm{Yb}^{3+} \mathrm{ET}\right)$ [47]. The latter process is observed in our case.

Furthermore, we analyzed the effect of the form of the sesquioxide material on the $\mathrm{Tb}^{3+}$ $\rightarrow 2 \mathrm{Yb}^{3+}$ ET by comparing the luminescence spectra of three materials: a commercial $\mathrm{Lu}_{2} \mathrm{O}_{3}$ powder, an $\mathrm{Yb}: \mathrm{Lu}_{2} \mathrm{O}_{3}$ nanopowder produced by laser ablation, sedimentation and calcination, and an $\mathrm{Yb}: \mathrm{Lu}_{2} \mathrm{O}_{3}$ ceramic, Fig. 14(b). Almost no $\mathrm{Yb}^{3+}$ emission is observed in the commercial (undoped) powder. In the visible, apart from the rare-earth ion impurity emissions, broad bands originating from defect states appear. For the nanopowder, both kinds of visible emissions are suppressed while the $\sim 1 \mu \mathrm{m}$ emission appears suggesting weak ET. Finally, for the ceramic, the $\mathrm{Yb}^{3+}$ emission is enhanced by an order of magnitude and the visible emissions are further diminished indicating much stronger ET.

For the $\mathrm{Yb}: \mathrm{Lu}_{3} \mathrm{~A}_{5} \mathrm{O}_{12}$ ceramics, Fig. 14(a), similar $\mathrm{Tb}^{3+}$ emissions are observed but the $\sim 1 \mu \mathrm{m} \mathrm{Yb}^{3+}$ luminescence is much weaker due to cooperative down-conversion. The latter suggests weaker effect of terbium impurity on $\mathrm{Yb}^{3+}$ laser performance. The rare-earth ion 
density in sesquioxides is higher than in garnets (for the same at.\%) which explains the higher content of $\mathrm{Tb}$ in $\mathrm{Yb}: \mathrm{Lu}_{2} \mathrm{O}_{3}$. It is known that cooperative energy-transfer processes are particularly strong in sesquioxides [47]. Thus, $\mathrm{Tb}^{3+}$ species directly act as quenching centers. $\mathrm{Tb}^{4+}$ species are formed during annealing serving as charge compensators for $\mathrm{Yb}^{2+}$ ions but also acting as strong quenching centers. As a consequence the presence of $\mathrm{Tb}^{3+}$ and $\mathrm{Tb}^{4+}$ may be responsible for the observed thermal roll-over and explains the coloration of the fabricated $\mathrm{Yb}: \mathrm{Lu}_{2} \mathrm{O}_{3}$ ceramics.

\section{Conclusions}

We presented a detailed comparative study of the microstructure, optical, vibronic and spectroscopic properties, and diode-pumped laser performance of two Yb-doped Lu-based oxide transparent ceramics, namely $\mathrm{Yb}: \mathrm{Lu}_{3} \mathrm{Al}_{5} \mathrm{O}_{12}$ (garnet) and $\mathrm{Yb}: \mathrm{Lu}_{2} \mathrm{O}_{3}$ (sesquioxide). These ceramics were synthesized using the same nanopowders ( $\mathrm{Yb}: \mathrm{Lu}_{2} \mathrm{O}_{3}$ and $\mathrm{Al}_{2} \mathrm{O}_{3}$ ) produced by laser ablation by two different methods: solid-state reaction synthesis at $1800{ }^{\circ} \mathrm{C}$ for $5 \mathrm{~h}$ with a presence of a sintering aid (1 wt $\%$ TEOS) and vacuum pre-sintering followed by HIP at $207 \mathrm{MPa} / 1400{ }^{\circ} \mathrm{C}$ for $2 \mathrm{~h}$, respectively. The use of different methods was dictated by the different microstructure evolution of these materials during sintering (concerning the pore formation) and it led to a notable difference in the mean grain size: 14 and $0.4 \mu \mathrm{m}$ for $\mathrm{Yb}: \mathrm{Lu}_{3} \mathrm{Al}_{5} \mathrm{O}_{12}$ and $\mathrm{Yb}: \mathrm{Lu}_{2} \mathrm{O}_{3}$, respectively. Both ceramics exhibited low content of $\mu \mathrm{m}$-sized pores, a close-packed structure, high transmission at $\sim 1.1 \mu \mathrm{m}$ approaching the theoretical one, and relatively low passive losses at the $\mathrm{Yb}^{3+}$ laser wavelength.

Efficient continuous-wave laser operation under diode-pumping at $968 \mathrm{~nm}$ is achieved with both ceramics. The $\mathrm{Yb}: \mathrm{Lu}_{3} \mathrm{Al}_{5} \mathrm{O}_{12}$ ceramic outperformed its sesquioxide counterpart: a compact (microchip-type) laser generated $5.65 \mathrm{~W}$ at $1031.1 \mathrm{~nm}$ with a slope efficiency of $67.2 \%$ (fitting the linear part of the output dependence) and a laser threshold of $0.45 \mathrm{~W}$ and in the quasi-CW regime, the peak power was scaled up to $8.83 \mathrm{~W}$ (limited only by the available pump power). For the $\mathrm{Yb}: \mathrm{Lu}_{2} \mathrm{O}_{3}$ ceramic laser, the power scaling was limited (the $\mathrm{CW}$ output power reached $1.0 \mathrm{~W}$ at $1083 \mathrm{~nm}$ with $\eta=68.0 \%$ ) by the thermo-optic effects which are assigned to stronger heat dissipation due in part to the longer laser wavelength and in part to the impurity $\mathrm{Tb}^{3+}$ ions and possibly $\mathrm{Yb}^{2+}$ ions charge-compensation by $\mathrm{Tb}^{4+}$ species. These optical centers also determined a weak brown coloration of the $\mathrm{Yb}: \mathrm{Lu}_{2} \mathrm{O}_{3}$ ceramics.

Further power scaling of compact lasers based on both Lu-based oxide ceramics seems to be possible via several routes: (i) improvement of the ceramic quality by eliminating the effect of terbium impurity responsible for the formation of $\mathrm{Tb}^{3+}$ and $\mathrm{Yb}^{2+}$ centers, e.g., by purification of the nanopowders; (b) alleviating thermal effects using larger pump spot size or employing other geometries of the laser element providing more efficient cooling (e.g., slabshaped, as already demonstrated in the present work for $\mathrm{Yb}: \mathrm{Lu}_{3} \mathrm{Al}_{5} \mathrm{O}_{12}$ ceramics); (iii) using higher $\mathrm{Yb}$ doping levels up to 10 at.\% for better pump absorption efficiency.

The developed $\mathrm{Yb}: \mathrm{Lu}_{3} \mathrm{Al}_{5} \mathrm{O}_{12}$ ceramics are promising for thin-disk lasers and amplifiers at $\sim 1 \mu \mathrm{m}$.

\section{Acknowledgments}


This work was supported by the Spanish Government (project No. MAT2016-75716C2-1-R (AEI/FEDER,UE)); Generalitat de Catalunya (project No. 2017SGR755); Government of the Russian Federation (state task project No. 0389-2016-0002 (2018-2020)); RFBR (Grant No. 19-03-00855). The authors gratefully acknowledge Vyacheslav V. Platonov and Egor V. Tikhonov from IEP UrB RAS for providing $\mathrm{Yb}_{2} \mathrm{Lu}_{2} \mathrm{O}_{3}$ and $\mathrm{Al}_{2} \mathrm{O}_{3}$ nanopowders. L. B. thanks Mikhail Baranov from ITMO University for the help with the SEM studies.

\section{Declaration of competing interests}

The authors declare that they have no known competing financial interests or personal relationships that could have appeared to influence the work reported in this paper.

\section{References}

1. S. F. Wang, J. Zhang, D. W. Luo, F. Gu, D. Y. Tang, Z. L. Dong, G. E. B. Tan, W. X. Que, T. S. Zhang, S. Li, L. B. Kong, Transparent ceramics: Processing, materials and applications, Prog. Sol. State Chem. 41(1-2) (2013) 20-54.

2. A. Ikesue, Y. L. Aung, Ceramic laser materials, Nature Photon. 2(12) (2008) 721-727.

3. A. Ikesue, T. Kinoshita, K. Kamata, K. Yoshida, Fabrication and optical properties of highperformance polycrystalline Nd:YAG ceramics for solid-state lasers, J. Am. Ceram. Soc. 78(4) (1995) 1033-2040.

4. H. Yagi, T. Yanagitani, K. Takaichi, K. Ueda, A. A. Kaminskii, Characterizations and laser performances of highly transparent $\mathrm{Nd}^{3+}: \mathrm{Y}_{3} \mathrm{Al}_{5} \mathrm{O}_{12}$ laser ceramics, Opt. Mater. 29(10) (2007) 1258-1262.

5. J. Dong, A. Shirakawa, K. Ueda, H. Yagi, T. Yanagitani, A. A. Kaminskii, Laser-diode pumped heavy-doped Yb:YAG ceramic lasers, Opt. Lett. 32(13) (2007) 1890-1892.

6. D. Luo, J. Zhang, C. Xu, H. Yang, H. Lin, H. Zhu, D. Tang, Yb:LuAG laser ceramics: a promising high power laser gain medium, Opt. Mater. Express 2(10) (2012) 1425-1431.

7. O. L. Antipov, A. A. Novikov, N. G. Zakharov, A. P. Zinoviev, Optical properties and efficient laser oscillation at $2066 \mathrm{~nm}$ of novel Tm: $\mathrm{Lu}_{2} \mathrm{O}_{3}$ ceramics, Opt. Mater. Express 2(2) (2012) 183189.

8. W. X. Zhang, J. Zhou, W. B. Liu, J. Li, L. Wang, B. X. Jiang, Y. B. Pan, X. J. Cheng, J. Q. Xu, Fabrication, properties and laser performance of Ho:YAG transparent ceramic, J. Alloy Compd. 506(2) (2010) 745-748.

9. J. Lu, M. Prabhu, J. Song, C. Li, J. Xu, K. Ueda, A. A. Kaminskii, H. Yagi, T. Yanagitani, Optical properties and highly efficient laser oscillation of Nd:YAG ceramics, Appl. Phys. B 71(4) (2000) 469-473.

10. H. Nakao, T. Inagaki, A. Shirakawa, K. Ueda, H. Yagi, T. Yanagitani, A. A. Kaminskii, B. Weichelt, K. Wentsch, M. A. Ahmed, T. Graf, $\mathrm{Yb}^{3+}$-doped ceramic thin-disk lasers of Lu-based oxides, Opt. Mater. Express 4(10) (2014) 2116-2121.

11. J. Lu, J. Lu, T. Murai, K. Takaichi, T. Uematsu, K. Ueda, H. Yagi, T. Yanagitani, A. A. Kaminskii, $\mathrm{Nd}^{3+}: \mathrm{Y}_{2} \mathrm{O}_{3}$ ceramic laser, Jpn. J. Appl. Phys. 40(12A) (2001) L1277-L1279. 
12. J. Lu, J. F. Bisson, K. Takaichi, T. Uematsu, A. Shirakawa, M. Musha, K. Ueda, H. Yagi, T. Yanagitani, A. A. Kaminskii, $\mathrm{Yb}^{3+}: \mathrm{Sc}_{2} \mathrm{O}_{3}$ ceramic laser, Appl. Phys. Lett. 83(6) (2003) 11011103.

13. W. Jing, P. Loiko, J. M. Serres, Y. Wang, E. Vilejshikova, M. Aguiló, F. Díaz, U. Griebner, H. Huang, V. Petrov, X. Mateos, Synthesis, spectroscopy, and efficient laser operation of "mixed" sesquioxide Tm:( $\mathrm{Lu}, \mathrm{Sc})_{2} \mathrm{O}_{3}$ transparent ceramics, Opt. Mater. Express 7(11) (2017) 4192-4202.

14. I. Shoji, S. Kurimura, Y. Sato, T. Taira, A. Ikesue, K. Yoshida, Optical properties and laser characteristics of highly $\mathrm{Nd}^{3+}$-doped $\mathrm{Y}_{3} \mathrm{Al}_{5} \mathrm{O}_{12}$ ceramics, Appl. Phys. Lett. 77(7) (2000) 939-941. 15. G. Toci, A. Pirri, B. Patrizi, R. N. Maksimov, V. V. Osipov, V. A. Shitov, A. S. Yurovskikh, M. Vannini, High efficiency emission of a laser based on $\mathrm{Yb}$-doped $(\mathrm{Lu}, \mathrm{Y})_{2} \mathrm{O}_{3}$ ceramic, Opt. Mater. 83 (2018) 182-186.

16. J. Kong, D. Y. Tang, B. Zhao, J. Lu, K. Ueda, H. Yagi, T. Yanagitani, 9.2-W diode-endpumped $\mathrm{Yb}: \mathrm{Y}_{2} \mathrm{O}_{3}$ ceramic laser, Appl. Phys. Lett. 86(16) (2005) 161116-1-3.

17. C. W. Xu, D. W. Luo, J. Zhang, H. Yang, X. P. Qin, W. D. Tan, D. Y. Tang, Diode pumped highly efficient $\mathrm{Yb}: \mathrm{Lu}_{3} \mathrm{Al}_{5} \mathrm{O}_{12}$ ceramic laser, Laser Phys. Lett. 9(1) (2012) 30-34.

18. H. Nakao, A. Shirakawa, K. Ueda, H. Yagi, and T. Yanagitani, CW and mode-locked operation of $\mathrm{Yb}^{3+}$-doped $\mathrm{Lu}_{3} \mathrm{Al}_{5} \mathrm{O}_{12}$ ceramic laser, Opt. Express 20(14) (2012) 15385-15391. 19. M. Tokurakawa, A. Shirakawa, K. Ueda, H. Yagi, T. Yanagitani, A. A. Kaminskii, Diodepumped sub-100 fs Kerr-lens mode-locked $\mathrm{Yb}^{3+}: \mathrm{Sc}_{2} \mathrm{O}_{3}$ ceramic laser, Opt. Lett. 32(23) (2007) 3382-3384.

20. M. Tokurakawa, A. Shirakawa, K. Ueda, H. Yagi, T. Yanagitani, A. A. Kaminskii, K. Beil, C. Kränkel, G. Huber, Continuous wave and mode-locked $\mathrm{Yb}^{3+}: \mathrm{Y}_{2} \mathrm{O}_{3}$ ceramic thin disk laser, Opt. Express 20(10) (2012) 10847-10853.

21. K. Beil, S. T. Fredrich-Thornton, F. Tellkamp, R. Peters, C. Kränkel, K. Petermann, G. Huber, Thermal and laser properties of $\mathrm{Yb}: \mathrm{LuAG}$ for $\mathrm{kW}$ thin disk lasers, Opt. Express 18(20) (2010) 20712-20722.

22. Y. Fu, J. Li, C. Wang, T. Xie, W. Li, L. Wu, Y. Pan, Fabrication and properties of highly transparent Yb:LuAG ceramics, J. Alloys Compd. 664 (2016) 595-601.

23. D. Luo, J. Zhang, C. Xu, H. Yang, H. Lin, H. Zhu, D. Tang, Yb:LuAG laser ceramics: a promising high power laser gain medium, Opt. Mater. Express 2(10) (2012) 1425-1431.

24. A. Brenier, Y. Guyot, H. Canibano, G. Boulon, A. Ródenas, D. Jaque, A. Eganyan, A. G. Petrosyan, Growth, spectroscopic, and laser properties of $\mathrm{Yb}^{3+}$-doped $\mathrm{Lu}_{3} \mathrm{Al}_{5} \mathrm{O}_{12}$ garnet crystal, J. Opt. Soc. Am. B 23(4) (2006) 676-683.

25. A. Pirri, M. Vannini, V. Babin, M. Nikl, G. Toci, CW and quasi-CW laser performance of 10 at.\% $\mathrm{Yb}^{3+}:$ LuAG ceramic, Laser Phys. 23(9) (2013) 095002-1-7.

26. L. Basyrova, R. Maksimov, V. Shitov, M. Baranov, V. Mikhaylovsky, A. Khubetsov, O. Dymshits, X. Mateos, P. Loiko, Effect of $\mathrm{SiO}_{2}$ addition on structural and optical properties of $\mathrm{Yb}: \mathrm{Lu}_{3} \mathrm{Al}_{5} \mathrm{O}_{12}$ transparent ceramics based on laser ablated nanopowders, J. Alloys Compd. 806, (2019) 717-725.

27. V. S. Kijko, R. N. Maksimov, V. A. Shitov, S. L. Demakov, A. S.Yurovskikh, Sintering of transparent $\mathrm{Yb}$-doped $\mathrm{Lu}_{2} \mathrm{O}_{3}$ ceramics using nanopowder produced by laser ablation method, J. Alloys Compd. 643 (2015) 207-211. 
28. C. Ma, F. Tang, J. Zhu, M. Du, X. Yuan, Y. Yu, K. Wang, Z. Wen, J. Zhang, J. Long, W. Guo, Y. Cao, Spectral and laser properties of Yb:LuAG transparent ceramics fabricated by tape casting method, J. Am. Ceram. Soc. 99(10) (2016) 3267-3272.

29. W. H. Rhodes, Y. Wang, C. Brecher, and J. G. Baldoni, Loss and recovery of transparency in pressure-consolidated $\mathrm{Lu}_{3} \mathrm{Al}_{5} \mathrm{O}_{12}$, J. Am. Ceram. Soc. 94(11) (2011) 3655-3658.

30. R. D. Shannon, Revised effective ionic radii and systematic studies of interatomic distances in halides and chalcogenides, Acta Cryst. A 32(5) (1976) 751-767.

31. M. Guzik, J. Pejchal, A. Yoshikawa, A. Ito, T. Goto, M. Siczek, T. Lis, G. Boulon, Structural investigations of $\mathrm{Lu}_{2} \mathrm{O}_{3}$ as single crystal and polycrystalline transparent ceramic, Cryst. Growth Des. 14(7) (2014) 3327-3334.

32. C. Kränkel, Rare-earth-doped sesquioxides for diode-pumped high-power lasers in the 1-, 2-, and 3- $\mu \mathrm{m}$ spectral range, IEEE J. Sel. Top. Quantum Electron. 21(1) (2014) 250-262 (2014).

33. Y. Kuwano, K. Suda, N. Ishizawa, T. Yamada, Crystal growth and properties of $(\mathrm{Lu}, \mathrm{Y})_{3} \mathrm{Al}_{5} \mathrm{O}_{12}$, J. Cryst. Growth 260(1-2) (2004) 159-164.

34. D. E. Zelmon, J. M. Northridge, N. D. Haynes, D. Perlov, K. Petermann, Temperaturedependent Sellmeier equations for rare-earth sesquioxides, Appl. Opt. 52(16) (2013) 3824-3828 (2013).

35. S. A. Payne, L. L. Chase, L. K. Smith, W. L. Kway, W. F. Krupke, Infrared cross-section measurements for crystals doped with $\mathrm{Er}^{3+}, \mathrm{Tm}^{3+}$ and $\mathrm{Ho}^{3+}$, IEEE J. Quantum Electron. 28(11) (1992) 2619-2630.

36. Y. Guyot, M. Guzik, G. Alombert-Goget, J. Pejchal, A. Yoshikawa, A. Ito, T. Goto, G. Boulon, Assignment of $\mathrm{Yb}^{3+}$ energy levels in the $\mathrm{C}_{2}$ and $\mathrm{C}_{3 \mathrm{i}}$ centers of $\mathrm{Lu}_{2} \mathrm{O}_{3}$ sesquioxide either as ceramics or as crystal, J. Lumin. 170 (2016) 513-519.

37. B. Aull, H. Jenssen, Vibronic interactions in Nd:YAG resulting in nonreciprocity of absorption and stimulated emission cross sections, IEEE J. Quantum Electron. 18(5) (1982) 925930.

38. R. Peters, C. Kränkel, K. Petermann, G. Huber, Crystal growth by the heat exchanger method, spectroscopic characterization and laser operation of high-purity $\mathrm{Yb}: \mathrm{Lu}_{2} \mathrm{O}_{3}$, J. Cryst. Growth 310(7-9) (2008) 1934-1938.

39. A. A. Kaminskii, H. Rhee, O. Lux, H. J. Eichler, S. N. Bagayev, H. Yagi, K. Ueda, A. Shirakawa, J. Dong, Stimulated Raman scattering in "garnet" $\mathrm{Lu}_{3} \mathrm{Al}_{5} \mathrm{O}_{12}$ ceramics-a novel hostmateriel for Ln-and TM-lasant ions, Laser Phys. Lett. 8(6) (2011) 458-464.

40. N. D. Todorov, M. V. Abrashev, V. Marinova, M. Kadiyski, L. Dimowa, E. Faulques, Raman spectroscopy and lattice dynamical calculations of $\mathrm{Sc}_{2} \mathrm{O}_{3}$ single crystals, Phys. Rev. B 87(10) (2013) 104301-1-5.

41. J. M. Serres, V. Jambunathan, P. Loiko, X. Mateos, H. Yu, H. Zhang, J. Liu, A. Lucianetti, T. Mocek, K. Yumashev, U. Griebner, V. Petrov, M. Aguiló, F. Díaz, Microchip laser operation of Yb-doped gallium garnets, Opt. Mater. Express 6(1) (2016) 46-57.

42. J. Dong, K. Ueda, A. A. Kaminskii, Laser-diode pumped efficient Yb:LuAG microchip lasers oscillating at 1030 and $1047 \mathrm{~nm}$, Laser Phys. Lett. 7(10) (2010) 726-733.

43. A. Pirri, G. Toci, M. Nikl, V. Babin, M. Vannini, Experimental evidence of a nonlinear loss mechanism in highly doped Yb:LuAG crystal, Opt. Express 22(4) (2014) 4038-4049. 
44. J. Sanghera, J. Frantz, W. Kim, G. Villalobos, C. Baker, B. Shaw, B. Sadowski, M. Hunt, F. Miklos, A. Lutz, I. Aggarwal, $10 \% \mathrm{Yb}^{3+}-\mathrm{Lu}_{2} \mathrm{O}_{3}$ ceramic laser with $74 \%$ efficiency, Opt. Lett. 36(4) (2011) 576-578.

45. V. Peters, Growth and spectroscopy of ytterbium doped sesquioxides, PhD Thesis, Hamburg University, 2001.

46. A. Pandey, V. K. Rai, K. Kumar, Influence of $\mathrm{Li}^{+}$codoping on visible emission of $\mathrm{Y}_{2} \mathrm{O}_{3}: \mathrm{Tb}^{3+}$, $\mathrm{Yb}^{3+}$ phosphor, Spectrochim. Acta A 118 (2014) 619-623.

47. J.-L. Yuan, X.-Y. Zeng, J.-T. Zhao, Z.-J. Zhang, H.-H. Chen, X.-X. Yang, Energy transfer mechanisms in $\mathrm{Tb}^{3+}, \mathrm{Yb}^{3+}$ codoped $\mathrm{Y}_{2} \mathrm{O}_{3}$ downconversion phosphor, J. Phys. D: Appl. Phys. 41(10) (2008) 105406-1-6. 


\section{List of figure captions}

Figure 1. Photograph of $\mathrm{Yb}: \mathrm{Lu}_{3} \mathrm{Al}_{5} \mathrm{O}_{12}$ (left) and $\mathrm{Yb}: \mathrm{Lu}_{2} \mathrm{O}_{3}$ (right) ceramic disks after annealing.

Figure 2. Effect of the annealing temperature and duration on the transmission of an $\mathrm{Yb}: \mathrm{Lu}_{2} \mathrm{O}_{3}$ ceramic disk (thickness: $t=1.0 \mathrm{~mm}$ ).

Figure 3. X-ray powder diffraction (XRD) patterns of (a) $\mathrm{Yb}_{\mathrm{Lu}} \mathrm{Lu}_{3} \mathrm{Al}_{5} \mathrm{O}_{12}$ and (b) $\mathrm{Yb}: \mathrm{Lu}_{2} \mathrm{O}_{3}$ ceramics, numbers denote the Miller's indices $(h k l)$. Blue bars positions of the diffraction peaks for cubic $\mathrm{Lu}_{3} \mathrm{Al}_{5} \mathrm{O}_{12}$ and $\mathrm{Lu}_{2} \mathrm{O}_{3}$ phases.

Figure 4. In-depth distribution of scattering centers in (a) $\mathrm{Yb}_{2} \mathrm{Lu}_{3} \mathrm{Al}_{5} \mathrm{O}_{12}(t=$ $1.75 \mathrm{~mm})$ and (b) $\mathrm{Yb}: \mathrm{Lu}_{2} \mathrm{O}_{3}(t=1.4 \mathrm{~mm})$ ceramics.

Figure 5. Scanning Electron Microscopy (SEM) images of the fracture surface of (a) $\mathrm{Yb}: \mathrm{Lu}_{3} \mathrm{Al}_{5} \mathrm{O}_{12}$ and (b) $\mathrm{Yb}: \mathrm{Lu}_{2} \mathrm{O}_{3}$ ceramics, insets: grain size distributions.

Figure 6. Low-signal transmission spectra of $\mathrm{Yb}: \mathrm{Lu}_{3} \mathrm{Al}_{5} \mathrm{O}_{12}$ and $\mathrm{Yb}: \mathrm{Lu}_{2} \mathrm{O}_{3}$ ceramic disks $(t=1.0 \mathrm{~mm})$, dashed curves - calculated Fresnel losses.

Figure 7. Room temperature spectroscopy of $\mathrm{Yb}^{3+}$ in $(\mathrm{a}, \mathrm{b}) \mathrm{Lu}_{3} \mathrm{Al}_{5} \mathrm{O}_{12}$ and (c,d) $\mathrm{Lu}_{2} \mathrm{O}_{3}$ ceramics: $(\mathrm{a}, \mathrm{c})$ absorption, $\sigma_{\mathrm{abs}}$, and stimulated-emission $(\mathrm{SE}), \sigma \mathrm{SE}$, cross-section spectra for the ${ }^{2} \mathrm{~F}_{5 / 2} \leftrightarrow{ }^{2} \mathrm{~F}_{7 / 2}$ transition; (b,d) gain cross-sections, $\sigma_{\text {gain }}=\beta \sigma \mathrm{SE}-(1-\beta) \sigma_{\mathrm{abs}}$, where $\beta=N_{2}\left({ }^{2} \mathrm{~F}_{5 / 2}\right) / N_{\mathrm{Yb}}$ is the inversion ratio and $N_{2}$ is the population of the upper laser level.

Figure 8. Low-temperature $(6 \mathrm{~K})$ spectroscopy of $\mathrm{Yb}^{3+}$ in $\mathrm{Lu}_{3} \mathrm{Al}_{5} \mathrm{O}_{12}$ ceramics: (a) absorption spectrum, (b) luminescence spectrum, $\lambda_{\mathrm{exc}}=976 \mathrm{~nm}$. " $h v$ " - phonon sidebands; (c) Stark splitting of $\mathrm{Yb}^{3+}$ multiplets: $i=0 . .3$ and $j^{\prime}$ $=0^{\prime} . .2^{\prime}$ number the Stark sub-levels, values indicate their energy in $\mathrm{cm}^{-1}, \mathrm{Z}_{1(2)}$ are the partition functions for the lower (upper) multiplets.

Figure 9. Room temperature luminescence decay curves of $\mathrm{Yb}^{3+}$ in (a) $\mathrm{Lu}_{3} \mathrm{Al}_{5} \mathrm{O}_{12}$ and (b) $\mathrm{Lu}_{2} \mathrm{O}_{3}$ ceramics measured for powdered samples (plotted in a semi-log scale), symbols: experimental data, lines: their exponential fits, $\lambda_{\text {exc }}$ $=970 \mathrm{~nm}, \lambda_{\text {lum }}=1050 \mathrm{~nm}$.

Figure 10. Room temperature Raman spectra of (a) $\mathrm{Yb}: \mathrm{Lu}_{3} \mathrm{Al}_{5} \mathrm{O}_{12}$ and (b) $\mathrm{Yb}: \mathrm{Lu}_{2} \mathrm{O}_{3}$ ceramics, numbers denote the Raman frequencies in $\mathrm{cm}^{-1} . \lambda_{\mathrm{exc}}=488$ nm. 
Figure 11. (a) Scheme of the compact diode-pumped ytterbium ceramic laser: LD - laser diode, PM - pump mirror, OC - output coupler; (b) Typical profile of the output laser mode for the $\mathrm{Yb}: \mathrm{Lu}_{3} \mathrm{Al}_{5} \mathrm{O}_{12}$ ceramic laser.

Figure 12. Low-power diode-pumped laser performance of (a,b) 3.6 at.\% $\mathrm{Yb}: \mathrm{Lu}_{3} \mathrm{Al}_{5} \mathrm{O}_{12}$ and (c,d) 3.6 at.\% $\mathrm{Yb}: \mathrm{Lu}_{2} \mathrm{O}_{3}$ ceramics (microchip laser geometry): (a,c) input-output dependences, $\eta$ - slope efficiency; (b,d) typical laser emission spectra measured at $P_{\mathrm{abs}}=4 \mathrm{~W}$. In (c), the results for a hemispherical cavity are shown for comparison. The laser emission is unpolarized.

Figure 13. Thermal effects in the diode-pumped 3.6 at. $\% \mathrm{Yb}: \mathrm{Lu}_{3} \mathrm{Al}_{5} \mathrm{O}_{12}$ ceramic lasers: (a) CW and quasi-CW performance of the microchip laser; (b) Comparison of the $\mathrm{CW}$ performance of the microchip laser and the mini-slab laser, $\eta$-slope efficiency, $T_{\mathrm{OC}}=10 \%$.

Figure 14. (a) Luminescence spectra of $\mathrm{Yb}: \mathrm{Lu}_{3} \mathrm{Al}_{5} \mathrm{O}_{12}$ and $\mathrm{Yb}: \mathrm{Lu}_{2} \mathrm{O}_{3}$ ceramics under excitation in the blue. The spectra are normalized with respect to the visible emission. For the $\mathrm{Yb}: \mathrm{Lu}_{2} \mathrm{O}_{3}$ ceramic, the $\sim 1 \mu \mathrm{m}$ luminescence is divided by a factor of 10; (b) Luminescence spectra of a commercial $\mathrm{Lu}_{2} \mathrm{O}_{3}$ powder, laser-ablated and calcined $\mathrm{Yb}: \mathrm{Lu}_{2} \mathrm{O}_{3}$ nanopowder, and $\mathrm{Yb}: \mathrm{Lu}_{2} \mathrm{O}_{3}$ ceramic. 


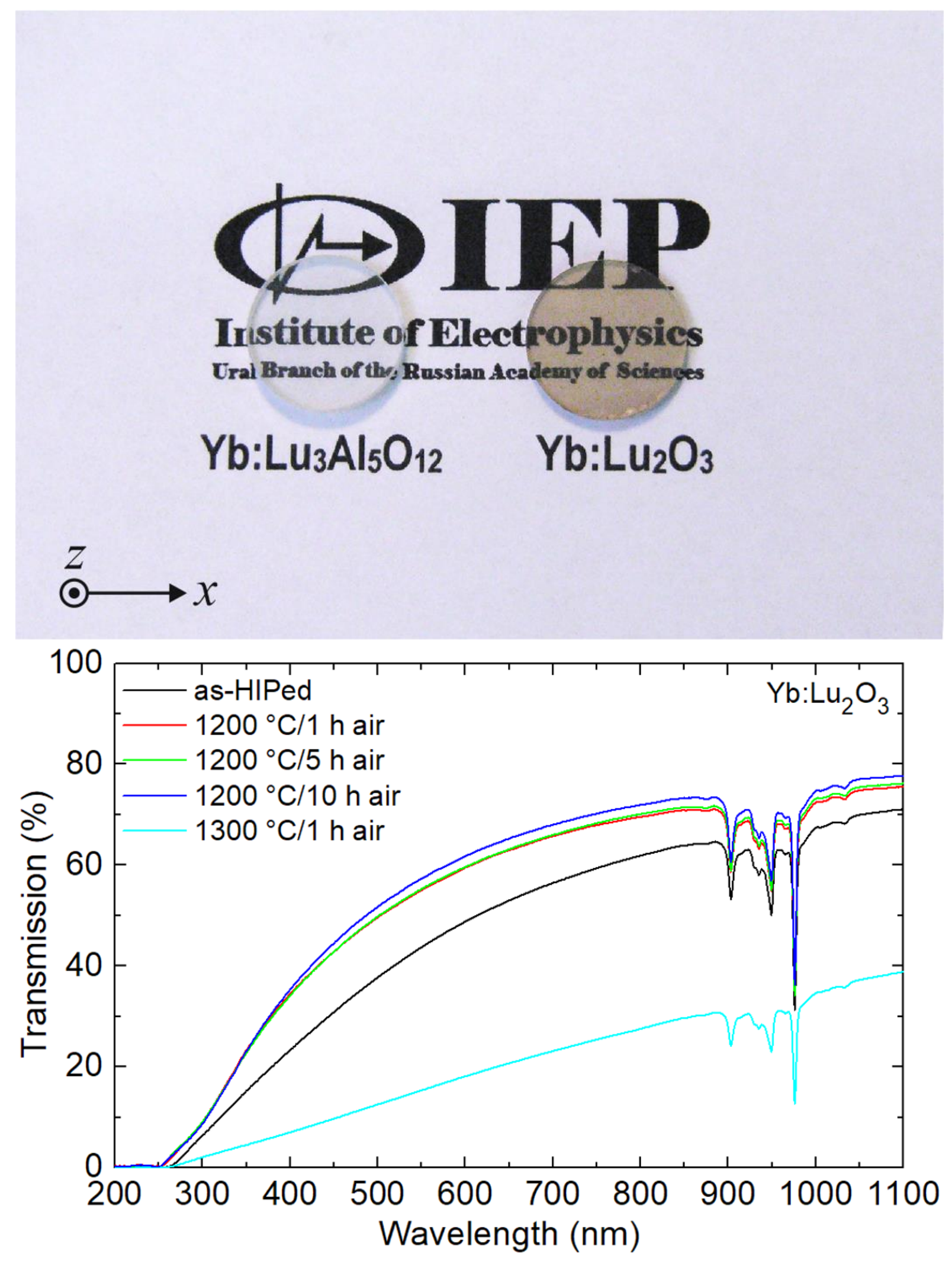



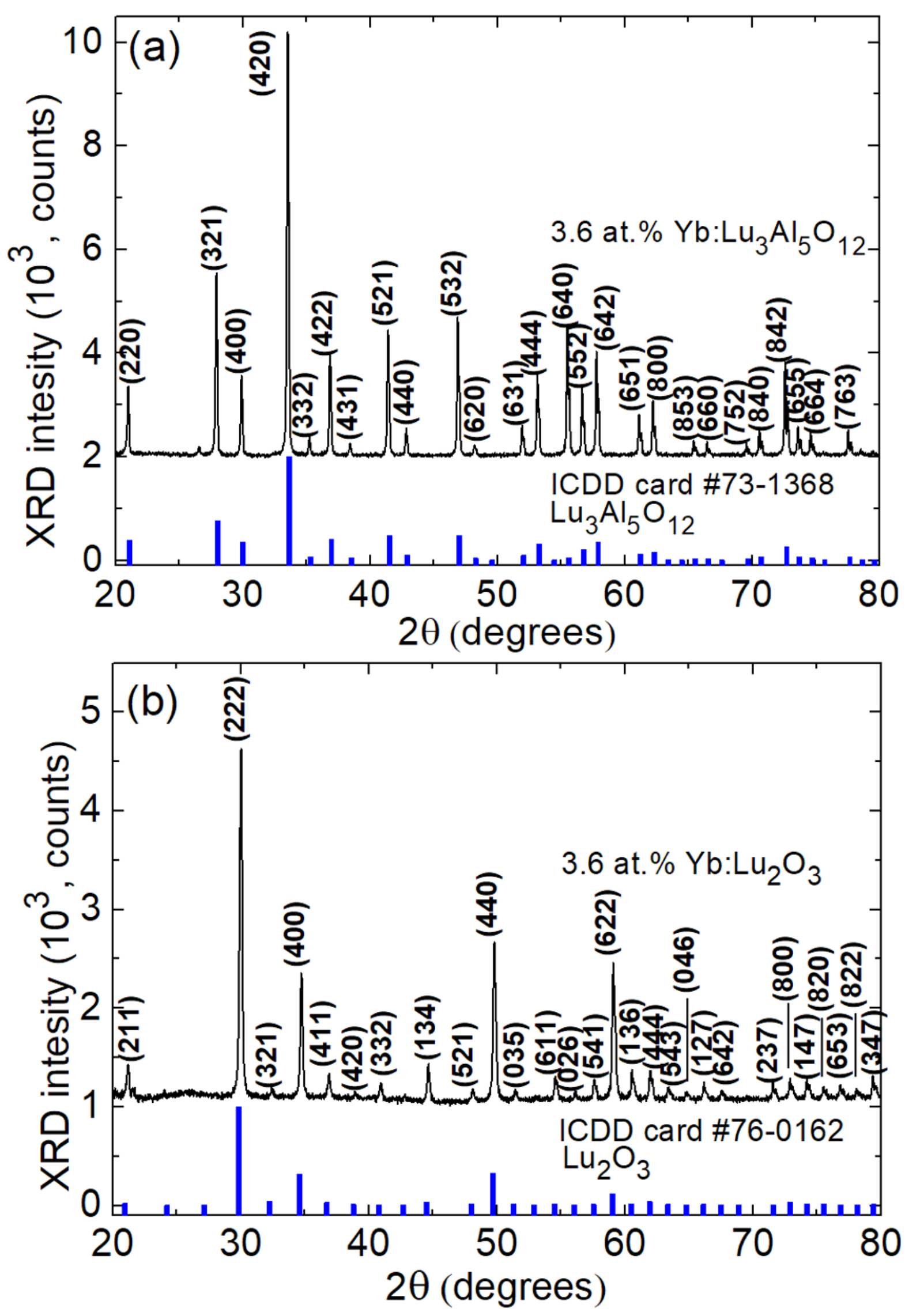

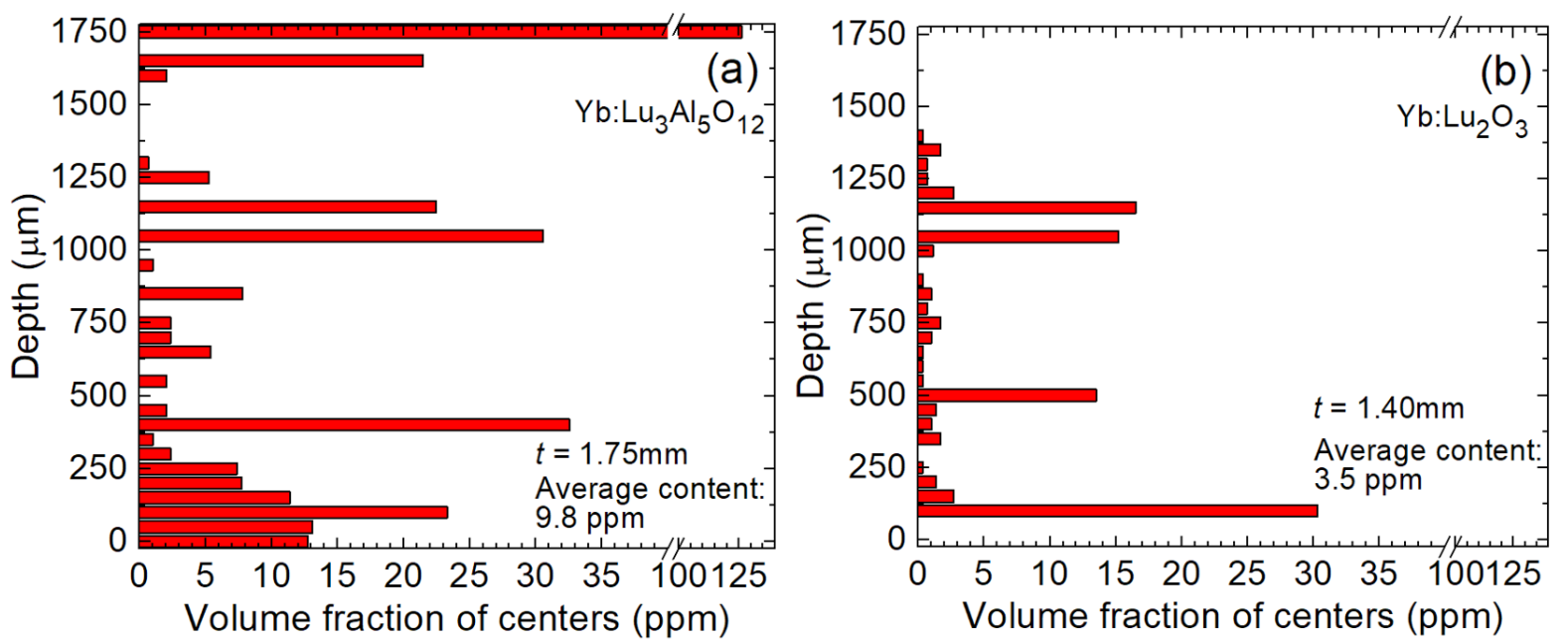

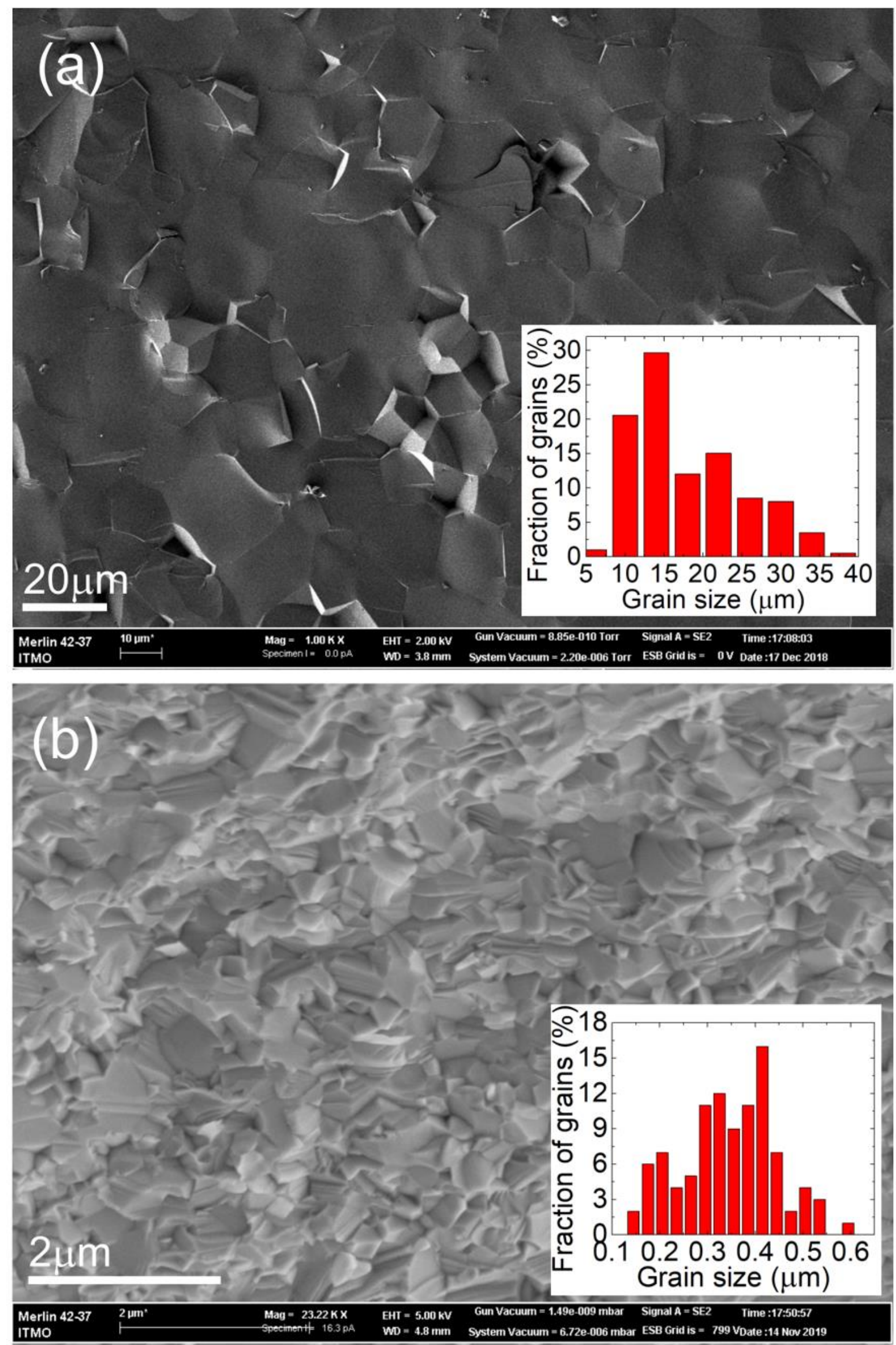

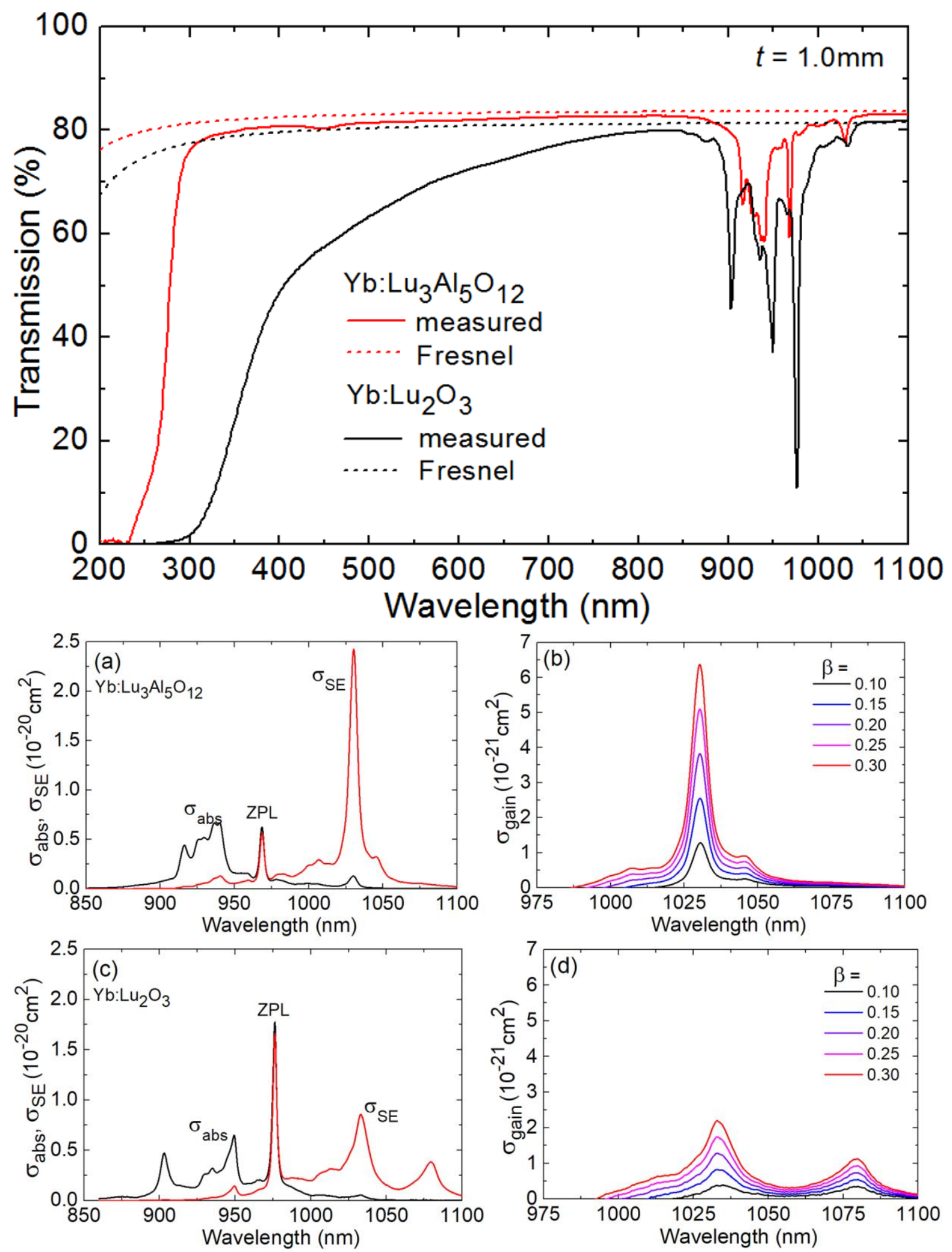

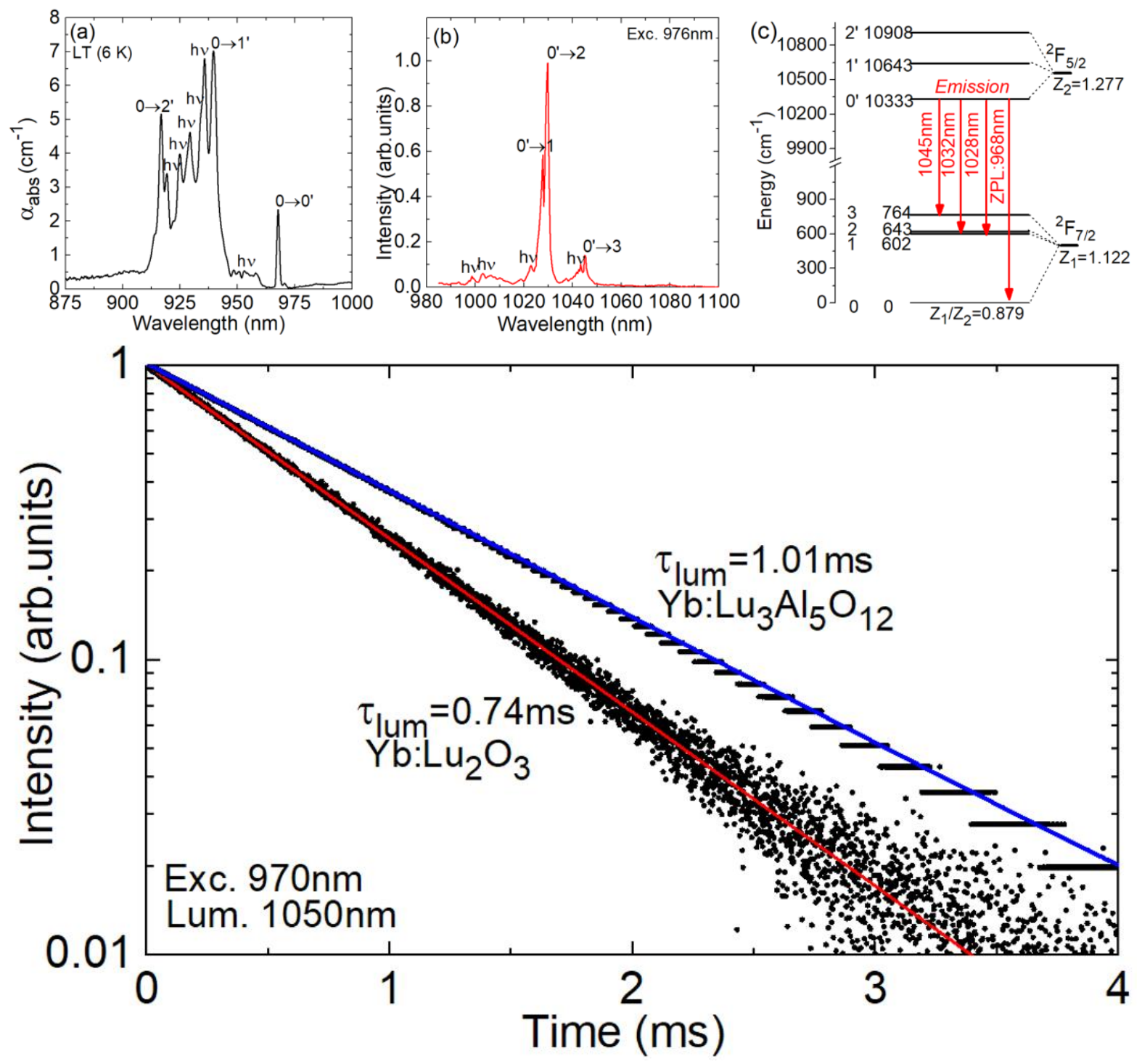

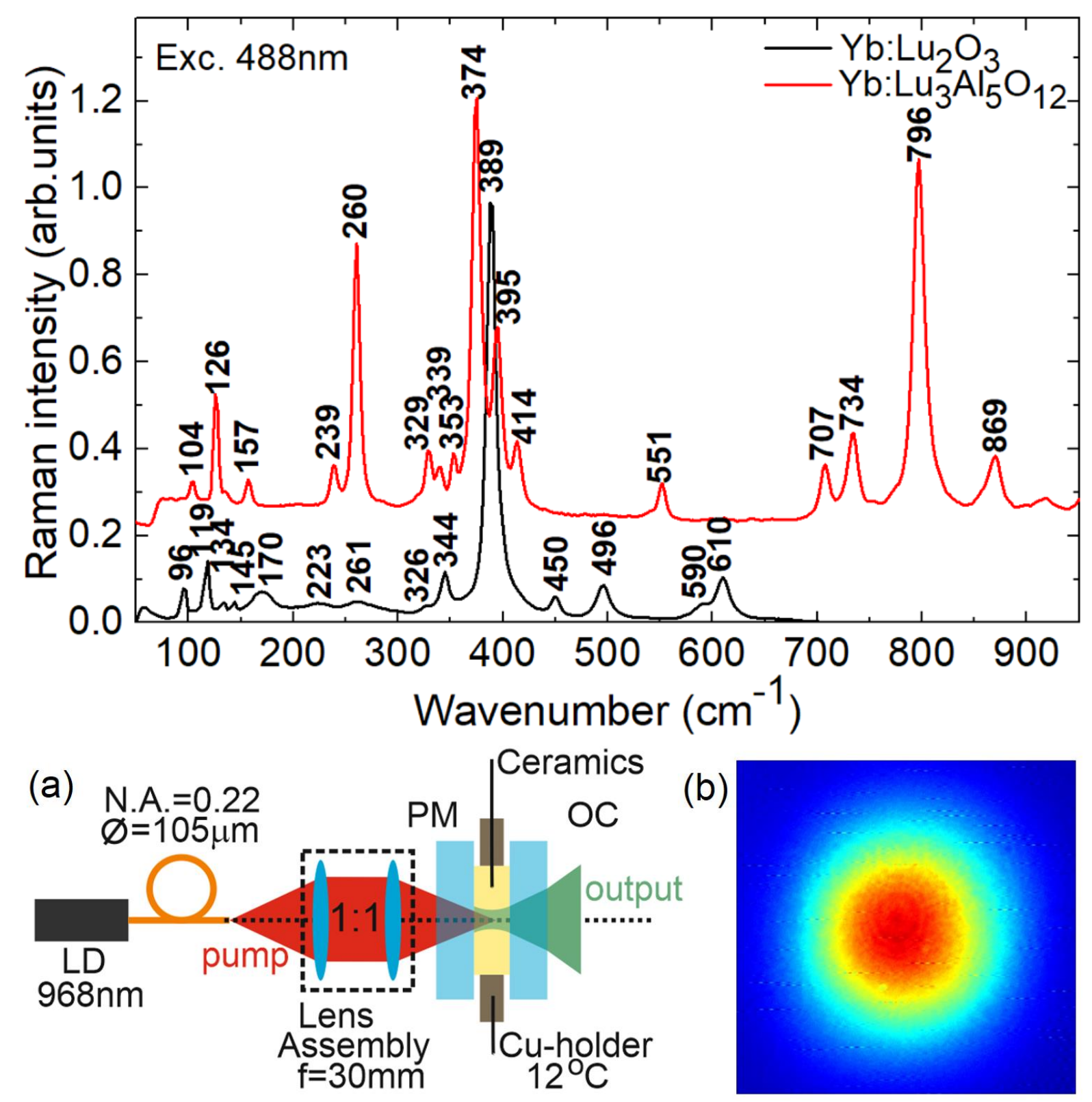

(b)

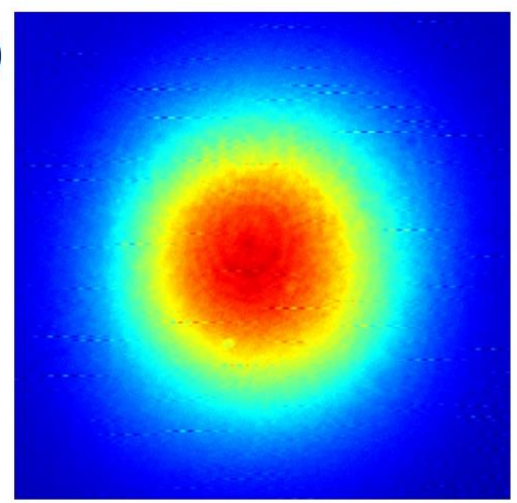



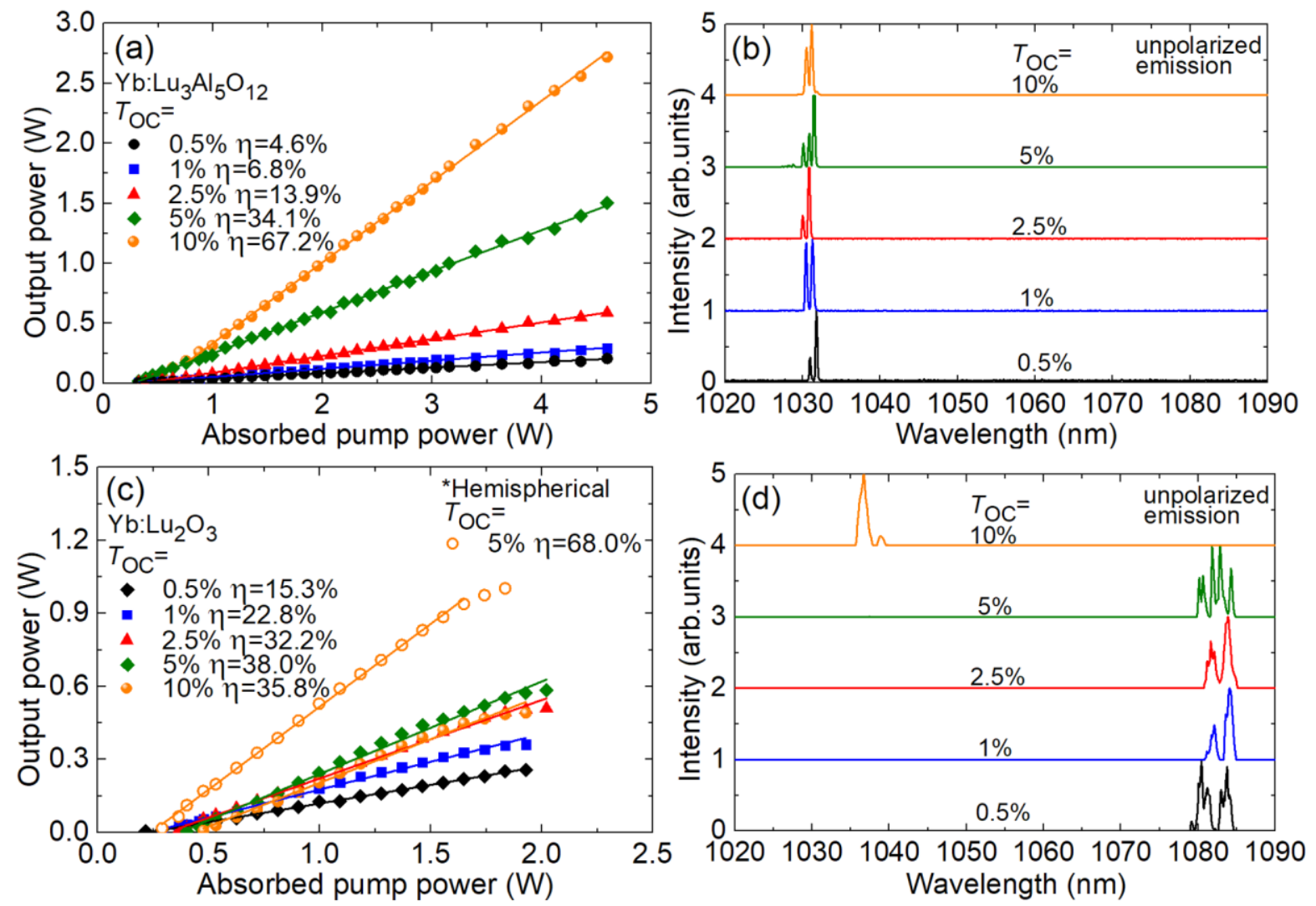

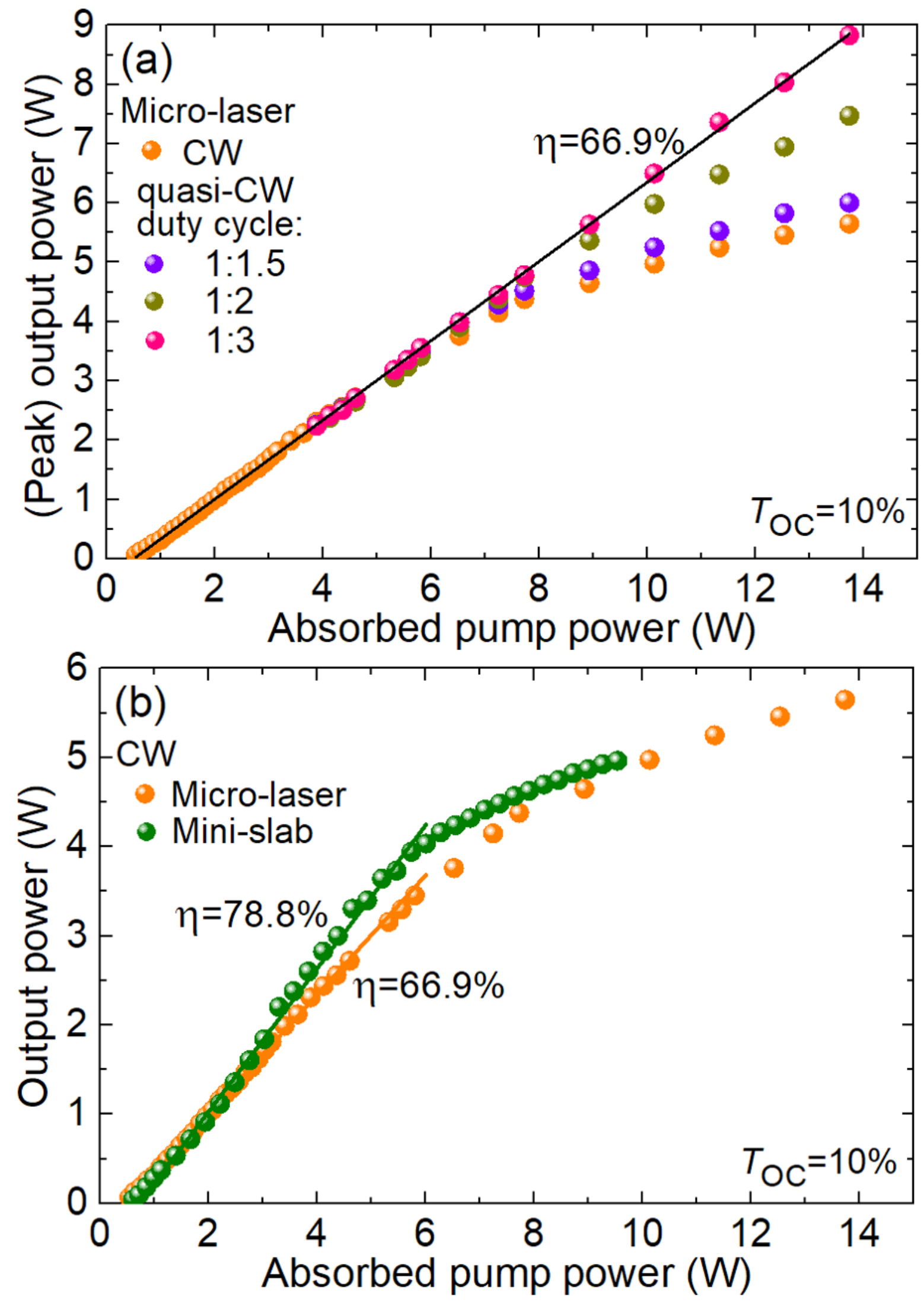

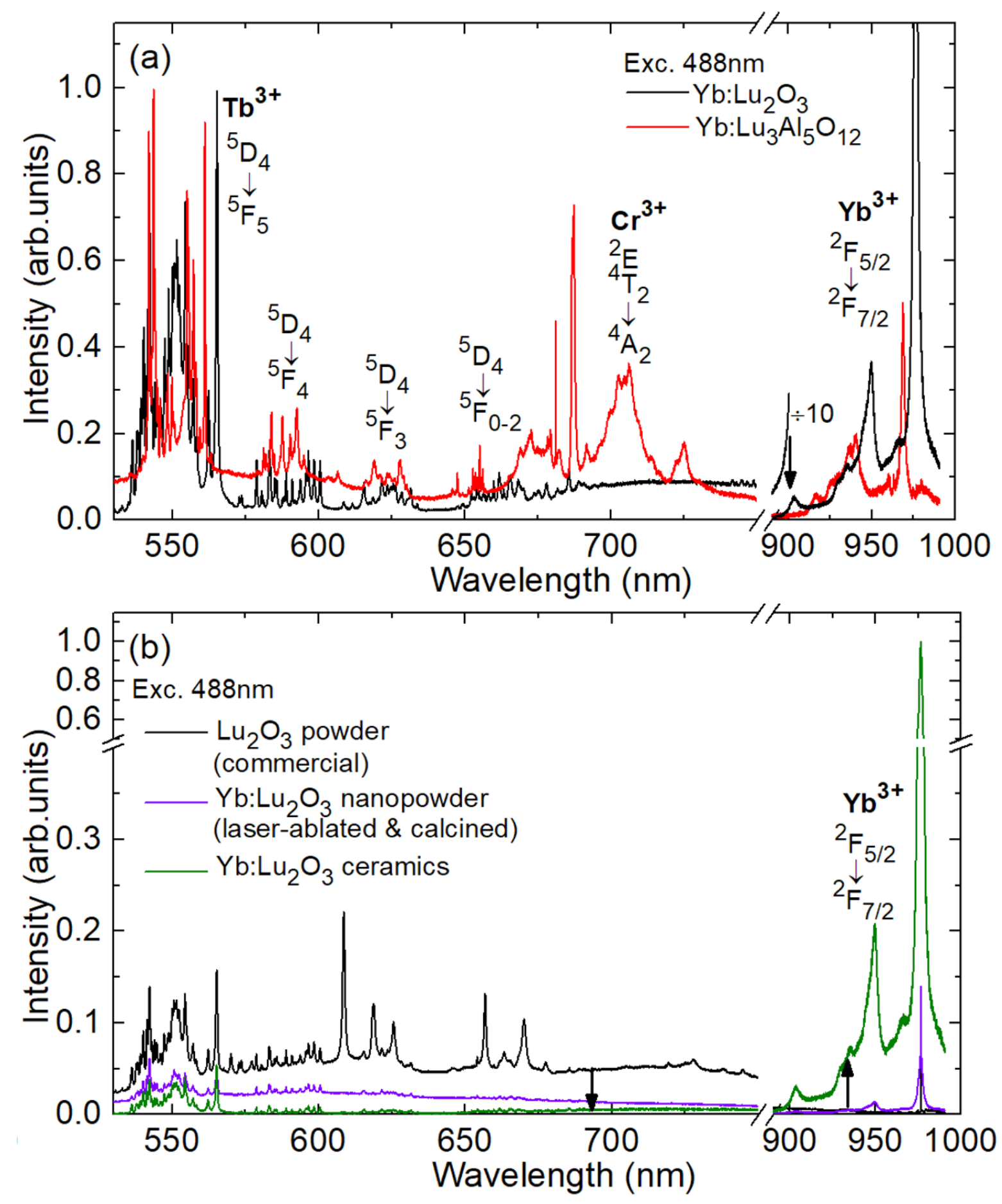
Table 1. Output characteristics ${ }^{a}$ of $\mathrm{Yb}: \mathrm{Lu}_{3} \mathrm{Al}_{5} \mathrm{O}_{12}$ crystalline and ceramic lasers.

\begin{tabular}{llllllll}
\hline Material & Doping, at.\% & $\lambda_{\mathrm{P}, \mathrm{nm}}$ & $P_{\text {th }}, \mathrm{W}$ & $P_{\text {out }}, \mathrm{W}$ & $\eta, \%$ & $\lambda_{\mathrm{L}}, \mathrm{nm}$ & Ref. \\
\hline Crystal & 12 & 970 & 0.75 & $0.17^{\mathrm{CW}}$ & $\sim 15$ & 1078 & {$[24]$} \\
Crystal & 5 & 940 & 0.15 & $1.63^{\mathrm{CW}}$ & 72 & 1030 & {$[42]$} \\
Crystal & 10 & 968 & 0.5 & $3.0^{\mathrm{CW}}$ & 35 & 1048 & {$[43]$} \\
& & 936 & 0.5 & $11.8^{\mathrm{qCW}}$ & 82 & 1046 & {$[43]$} \\
\hline Ceramics & 3.6 & 968 & 0.45 & $5.65^{\mathrm{CW}}$ & 67.2 & 1031 & $b$ \\
& & 968 & 0.45 & $8.83^{\mathrm{qCW}}$ & 66.9 & 1031 & $b$ \\
Ceramics & 5.0 & $\sim 980$ & $\sim 0.9$ & $7.2^{\mathrm{CW}}$ & 65 & 1030 & {$[23]$} \\
Ceramics & 10 & 940 & 0.47 & $2.14^{\mathrm{CW}}$ & 72 & 1032,1047 & {$[18]$} \\
Ceramics & 10 & 936 & $\sim 0.5$ & $6.0^{\mathrm{CW}}$ & 52 & 1030 & {$[25]$} \\
& & 936 & - & $8.83^{\mathrm{qCW}}$ & 60.2 & 1030 & {$[25]$} \\
\hline
\end{tabular}

${ }^{a} P_{\text {th }}-$ laser threshold, $P_{\text {out }}-$ output power, $\eta-$ slope efficiency (vs. absorbed pump power), $\lambda_{\mathrm{P}}-$ pump wavelength, $\lambda_{\mathrm{L}}-$ laser wavelength. ${ }^{b}$ This work. 